\title{
AVANCE AL ESTUDIO RADIOLÓGICO DEL ARMAMENTO DE LA NECRÓPOLIS IBÉRICA DEL CABECICO DEL TESORO (VERDOLAY, MURCIA). I. - LAS FALCATAS
}

\author{
POR \\ José Miguel García Cano* \\ MARIÁNGELES Gómez RÓDENAS ${ }^{* *}$
}

\section{RESUMEN - ABSTRACT}

Se presenta un nuevo estudio de las falcatas decoradas con damasquinados en plata de la necrópolis ibérica del Cabecico del Tesoro (Murcia), Se reestudian piezas conocidas y se presentan nuevos casos de decoraciones previamente ocultas bajo la corrosión pero visibles en un examen radiológico efectuado sobre las piezas.

We present a new study of the falcata swords decorated with silver inlay from the Iberian Iron Age cemetery at Cabecico del Tesoro (Murcia). Already known pieces are re-studied, while we also present new examples of previously unknown decorations, hidden under the corrosion layers but visible under radiographic examination.

\section{PALABRAS CLAVE - KeYWORDS}

Cultura Ibérica. Necrópolis. Cabecico del Tesoro. Armamento. Damasquinados. Estudios radiológicos.

Iberian Iron Age. Cemetery. Cabecico del Tesoro. Weapons. Silver inlay decoration. Radiographic analysis.

\section{INTRODUCCIÓN}

En las dos últimas décadas se ha avanzado de forma sustancial en el conocimiento del armamento ibérico, pudiéndose fijar de manera prácticamente definitiva las características tipológicas y morfológicas de su panoplia, desarrollada entre los siglos V-I anteriores de Cristo. Estos logros se han debido en esencia al trabajo, saber y dedicación de dos ilustres arqueólogos españoles los Dres. Emeterio Cuadrado Díaz (1987 y 1989) y Fernando Quesada Sanz (1989 y 1997). El posterior auge de estudios sistemáticos consagrados a dicho armamento ha supuesto el correcto inventario, publicación y difusión de amplias series de armas que han enriquecido de manera notable la panoplia ibérica, sobre todo de las ricas necrópolis del sureste penínsular, principalmente de las provincias de Alicante, yacimientos como la Serreta de Alcoy (Reig Seguí, 2000) o El Puntal (Salinas) (Sala y Hernández, 1998 y Hernández Alcaraz, 2005) y Murcia, donde podemos reseñar además de las ya mencionadas de Cigarra-

\footnotetext{
* Universidad de Murcia.

** Museo Arqueológico de Murcia.
} 
lejo (Cuadrado Díaz, 1989) y Cabecico del Tesoro (Quesada Sanz, 1989) los casos de Coimbra del Barranco Ancho (Jumilla) (García Cano, 1997a) y Castillejo de los Baños (Fortuna) (García Cano y Page del Pozo, 2001).

Algunas de las restauraciones realizadas para poder llevar a cabo los trabajos señalados con anterioridad, han puesto al descubierto decoraciones damasquinadas en plata en armas que a simple vista no eran visibles al ojo humano, debido por lo general a la mala conservación de los items con una fuerte capa de oxidación en la superficie. Estos hallazgos han hecho que cada vez con más frecuencia se hagan los estudios radiológicos pertinentes, tanto para obtener el diagnóstico de la patología de la pieza de cara a su mejor conservación, como para saber con precisión que armas estuvieron decoradas y cuales no ${ }^{1}$.

Esta línea argumental es la que se ha seguido en el presente trabajo, ya que con motivo de la restauración de algunas piezas de la exposición permanente del Museo Arqueológico de Murcia, se hizo necesaria la realización de radiografías a algunas falcatas ya que conocíamos la existencia -o posible existencia- de nielados de plata que pudieran sufrir daños durante dichos trabajos $^{2}$. El Centro Nacional de Formación Profesional y Ocupacional de Cartagena nos facilitó el acceso a un equipo de rayos «X» industrial en cabina autónoma manejada desde un panel exterior y equipado con un intensificador de imagen al que se le aplicó un tratamiento informático. Los importantes resultados derivados del análisis de tres ejemplares, nos animaron a realizar un estudio integral de todas las falcatas de la necrópolis del Cabecico del Tesoro, colección que actualmente se encuentra depositada de forma íntegra en el Museo Arqueológico de Murcia. Para ello, se realizó un estudio exhaustivo de los ajuares de la necrópolis y revisamos todas las falcatas preservadas en la actualidad. A continuación, se efectuaron radiografías a la práctica totalidad de las falcatas, exceptuando algunas que presentaban un pésimo estado de conservación. El propósito, como ya apuntamos anteriormente era reconocer todas aquellas decoradas con damasquinados para evitar que éstos se perdieran en futuras intervenciones sobre las piezas. Los análisis han resultado ser de gran interés por lo que en el presente estudio nos centraremos precisamente en las falcatas que presentan decoración, aunque también realizaremos una breve descripción de los elementos significativos de las restantes falcatas derivado del trabajo general hecho de todos los materiales de esta importante necrópolis ibérica.

\section{La necrópolis ibérica del CABecico del Tesoro (Verdolay, Murcia)}

Ubicada en el Verdolay, área residencial de La Alberca, pedanía muy próxima a la ciudad de Murcia. Se repite en esta zona la distribución del territorio característica de muchos yacimientos de tradición ibérica del sureste, existiendo a poca distancia de la necrópolis una zona de poblado en Santa Catalina del Monte ${ }^{3}$ y un santuario, en las inmediaciones del ere-

\footnotetext{
${ }^{1}$ Los análisis radiológicos podían ser considerados excepcionales hace 25 o 30 años (Véase p.e. Nieto Gallo y Escalera, 1970). Sin embargo con el desarrollo que ha experimentado la investigación en España en todos los órdenes estos trabajos multidisciplinares deben convertirse en uno más de los necesarios que se tienen que realizar para obtener un conocimiento completo de la morfología del armamento ibérico.

2 Gracias a las facilidades y predisposición del Centro Nacional de Formación Profesional y Ocupacional situado en Cartagena dependiente del Servicio Regional de Empleo y Formación de la Consejería de Trabajo de la Región de Murcia, y más en concreto a la buena fe y entusiasmo de Ramón Moreno González, Fernando Martínez Rivas y Francisco José Alcaraz Pérez, que realizaron las radiografías y el tratamiento informático, los resultados de este trabajo se pueden hoy presentar. De igual forma, agradecemos a Pilar Morales Muñoz, que realizó el tratamiento de imagen y el reportaje fotográfico y a José Gabriel Gómez Carrasco que realizó la gráfica su imprescindible colaboración. Por último agradecer a nuestro buen amigo Fernando Quesada el entusiasmo que ha puesto para que el artículo se publicara en Gladius.

3 Ha sido excavado, aunque solamente de manera parcial, a partir de finales de los años setenta del siglo pasado. (Poyato Holgado, 1979:531-543; Ros Sala, 1988:77-88; Ruiz Sanz, 1998:77-116).
} 
mitorio de La Luz. ${ }^{4}$ Este conjunto ibérico se haya inmerso en las estribaciones de la sierra de Carrascoy, en una posición elevada sobre la confluencia del Guadalentín y el Segura, cuencas fluviales de primer orden que dotaron a la zona de un desarrollo económico notable y de una situación privilegiada en el control de las principales vías terrestres de comunicación desde al menos la edad del Bronce (Ros Sala, 1989: 45).

Quizás la primera noticia que se tiene del conjunto ibérico de Verdolay se remonta a las informaciones que Juan Lozano Santa cita en Contestania y Bastetania del Reino de Murcia, a finales del siglo XVIII, donde hace mención a una ciudad romana en El Palmar. La siguiente información data de principios de siglo XX, cuando los padres franciscanos del convento de Santa Catalina recogen una importante colección de materiales del área de poblado y necrópolis hoy desconocida ya que desapareció como consecuencia del incendio que tuvo lugar en el convento en el transcurso de la guerra civil española. (Pérez Mateos, 1947: 166169). Más tarde, a partir de 1932, Augusto Fernández de Avilés como director del Museo Arqueológico Provincial, prospecta la zona y en 1935 lleva a cabo, en colaboración con Cayetano de Mergelina, las primeras excavaciones arqueológicas que se realizan en dos campañas y que se vieron interrumpidas por el advenimiento de la guerra civil. (Fernández de Avilés, 1941: 70-77; id., 1942: 97-118). Hasta esa fecha se habían producido excelentes resultados y habían sido excavadas y catalogadas más de ciento cincuenta sepulturas. Los materiales, cuyo depósito último era el Museo Arqueológico Provincial, fueron trasladados a la Universidad de Valladolid para proceder a su restauración. Un antiguo colaborador y discípulo de aquellos, Gratiniano Nieto Gallo, retoma la actividad y excava en el yacimiento en 1942 y 1944, localizando 302 nuevas incineraciones y convirtiéndose en el principal investigador del yacimiento. Finalmente las investigaciones se suspenden por falta de financiación económica y no se retoman hasta 1955, cuando Gratiniano Nieto Gallo y Manuel Jorge Aragoneses realizan una intervención motivada por el cambio de propiedad de la finca donde se ubica el yacimiento. Los resultados de aquellas campañas fueron también muy satisfactorios llegándose a rescatar un total de ciento treinta sepulturas. Aunque la memoria de Gratiniano Nieto perteneció inédita, sí que se aportaron algunas noticias de los trabajos de campo. (Nieto Gallo, 1942-1943; id., 1943-1944; id., 1947). Las últimas excavaciones, realizadas entre 1989 у 1993 por uno de nosotros (José Miguel García Cano) a lo largo de cinco campañas, permitieron delimitar el yacimiento y dieron lugar a la aparición de otros catorce enterramientos más que, unidos a los 594 exhumados con anterioridad, dieron la suma total de 609 tumbas $^{5}$.

Como hemos visto, el yacimiento fue objeto de intervenciones arqueológicas a lo largo de más de cincuenta años, en el transcurso de los cuales hubo enormes lapsos de tiempo en los que la necrópolis permaneció prácticamente abandonada y en el que el conocimiento que se tenía del mismo era sesgado. A partir de la década de los setenta del siglo XX empieza a aumentar el número de investigaciones ${ }^{6}$ que, junto con las últimas excavaciones realizadas, permiten conocerlo de una manera general y fecharlo entre finales del siglo $\mathrm{V}$ y el tránsito entre los siglos II-I a. C.

4 Tras sufrir numerosos y conocidos expolios a lo largo del siglo XX (Bosch Gimpera, 1924:4-5; id., 1931:162-171; Mergelina y Luna, 1926; Jorge Aragoneses, 1968-1969:317-346; id., 1973: 197-225), el yacimiento ha sido excavado sistemáticamente entre 1990 y 2002 (Lillo Carpio, 1991-1992:107-142; id.,19931994:155-174; id., 1995-1996:95-128; id., 1996:87-103; id., 1997:115-135; id., 1998:121-141; id., 1999:223 235; id., 2002a: 201-212; id., 2002b:205-217).

5 García Cano, 1993:83-91; id., 1996:105-113; id., 1997b:109-114; id., 1998:143-165.

6 Existe una bibliografía relativamente numerosa al respecto referida fundamentalmente a aspectos de la cultura material. (García Sandoval, 1962; Poyato Holgado, 1975; Broncano Rodríguez, 1978; García Cano et alii, 1989; Quesada Sanz, 1989; Conde Berdós, 1990; Ruiz Bremón, 1991; Sánchez Meseguer y Quesada Sanz, 1992; Page del Pozo y García Cano, 1993, entre otros). Para un resumen completo de la historia de la investigación véase en último lugar García Cano y Page del Pozo, 2004). 


\section{LAS FALCATAS DE LA NECRÓPOLIS}

No es motivo del presente artículo dar a conocer el estudio de cada una de las falcatas que se han documentado en la necrópolis. Nos centraremos fundamentalmente en presentar el catálogo de todas aquellas que llevan decoración. No obstante nos parecía de interés rescatar algunos datos morfológicos de las falcatas que posiblemente puedan ser analizados de manera pormenorizada en estudios posteriores (Tabla 1).

\begin{tabular}{|c|c|c|c|c|c|c|c|}
\hline N. ${ }^{0} \mathrm{INV}$. & SEP. & $\begin{array}{l}\text { CRONO- } \\
\text { LOGÍA }\end{array}$ & DESCRIPCIÓN & EMPUÑADURA & HOJA & MEDIDAS & $\begin{array}{l}\text { DECO- } \\
\text { RACIÓN }\end{array}$ \\
\hline 0/49/41/7 & 41 & $150-125 \mathrm{a} . \mathrm{C}$ & $\begin{array}{l}\text { Incompleta. } \\
\text { Aspecto estilizado. }\end{array}$ & $\begin{array}{l}\text { Fragmentada. } \\
\text { Fragmentos de la } \\
\text { barra maciza de unión. }\end{array}$ & $\begin{array}{l}\text { Acanaladuras } \\
\text { indeterminadas. }\end{array}$ & $\begin{array}{l}\text { Long. máx.: } 56,5 \mathrm{~cm} \text {; } \\
\text { Anch. máx.: } 5,8 \mathrm{~cm} \text {; } \\
\text { Anch. min.: } 3,4 \mathrm{~cm} .\end{array}$ & No \\
\hline 0/49/160/6 & 160 & 150-100 a.C & $\begin{array}{l}\text { Incompleta. } \\
\text { Aspecto macizo. }\end{array}$ & $\begin{array}{l}\text { Conserva las guardas } \\
\text { basales. }\end{array}$ & $\begin{array}{l}\text { Fragmentos que no unen } \\
\text { entre sí. Acanaladuras: } \\
\text { divergen al acercarse a la } \\
\text { empuñadura. }\end{array}$ & $\begin{array}{l}\text { Anch. máx.: 6,8 cm.; } \\
\text { Anch. mín.: 4,5 cm. }\end{array}$ & Sí \\
\hline $0 / 49 / 183 / 2$ & 183 & 400-300 a.C & $\begin{array}{l}\text { Incompleta. } \\
\text { Aspecto estilizado. } \\
\text { Doblada. }\end{array}$ & $\begin{array}{l}\text { Cabeza de caballo. } \\
\text { Conserva dos } \\
\text { remaches y guardas } \\
\text { basales. }\end{array}$ & $\begin{array}{l}\text { Completa y doblada a la } \\
\text { mitad. Acanaladuras } \\
\text { indeterminadas. }\end{array}$ & $\begin{array}{l}\text { Anch. máx.: } 5 \text { cm.; } \\
\text { Anch. mín.: } 2,8 \text { cm. }\end{array}$ & No \\
\hline 0/49/190/1 & 190 & Sin datos & $\begin{array}{l}\text { Incompleta. } \\
\text { Aspecto estilizado. } \\
\text { Botones de } \\
\text { sujeción al tahalí. }\end{array}$ & $\begin{array}{l}\text { En seis fragmentos. } \\
\text { Con reservas, forma } \\
\text { de cabeza de caballo y } \\
\text { barra maciza. }\end{array}$ & $\begin{array}{l}\text { Incompleta. } \\
\text { Acanaladuras } \\
\text { indeterminadas. }\end{array}$ & $\begin{array}{l}\text { Long. máx. } \\
\text { conservada: } 39,5 \mathrm{~cm} \text {; } \\
\text { Anch. máx.: } 6,5 \mathrm{~cm} \text {; } \\
\text { Anch. mín.: } 3,7 \mathrm{~cm} \text {. }\end{array}$ & No \\
\hline 0/49/197/1 & 197 & 175-100 a.C & $\begin{array}{l}\text { Incompleta. Alto } \\
\text { grado de } \\
\text { exfoliación. } \\
\text { Aspecto macizo. }\end{array}$ & & $\begin{array}{l}\text { Fragmentos del extremo } \\
\text { distal y proximal que no } \\
\text { unen entre sí. } \\
\text { Acanaladuras } \\
\text { indeterminadas. }\end{array}$ & & No \\
\hline 0/49/198/1 & 198 & $400-350$ a.C & $\begin{array}{l}\text { Incompleta. } \\
\text { Aspecto macizo. }\end{array}$ & $\begin{array}{l}\text { Cabeza de caballo. } \\
\text { Conserva guardas } \\
\text { basales y posible barra } \\
\text { maciza. }\end{array}$ & $\begin{array}{l}\text { Acanaladuras: divergen } \\
\text { al acercarse a la } \\
\text { empuñadura. Convergen } \\
\text { en extremo distal con } \\
\text { decoración. }\end{array}$ & $\begin{array}{l}\text { Long. total de la hoja } \\
\text { conservada: } 49,3 \mathrm{~cm} \text {; } \\
\text { Anch. máx.: 7,3 } \mathrm{cm} \text {; } \\
\text { Anch. mín.: } 4,2 \mathrm{~cm} .\end{array}$ & Sí \\
\hline $0 / 49 / 212 / 1$ & 212 & Sin datos & Incompleta. & & $\begin{array}{l}\text { Tres fragmentos que no } \\
\text { unen. Acanaladuras } \\
\text { indeterminadas. }\end{array}$ & & No. \\
\hline $0 / 49 / 220 / 3$ & 220 & 250-200 a.C & $\begin{array}{l}\text { Incompleta. } \\
\text { Aspecto macizo. }\end{array}$ & & $\begin{array}{l}\text { Fragmentos extremo } \\
\text { proximal. Acanaladuras } \\
\text { indeterminadas. }\end{array}$ & $\begin{array}{l}\text { Long. frag. } \\
\text { conservado: } 35,5 \mathrm{~cm} \text {. }\end{array}$ & No \\
\hline $0 / 49 / 226 / 14$ & 226 & 250-200 a.C & $\begin{array}{l}\text { Incompleta. } \\
\text { Aspecto macizo. }\end{array}$ & $\begin{array}{l}\text { Conserva guardas } \\
\text { basales, barra de } \\
\text { sujeción que es } \\
\text { maciza y un remache. }\end{array}$ & $\begin{array}{l}\text { Los fragmentos no unen } \\
\text { entre sí. Acanaladuras } \\
\text { indeterminadas. }\end{array}$ & $\begin{array}{l}\text { Long. total conservada: } \\
54,9 \text { cm.; Anch. máx.: } \\
6,4 ; \text { Anch. mín.: } 3,9 \\
\text { cm. }\end{array}$ & No \\
\hline $0 / 49 / 258 / 2$ & 258 & Sin datos & Incompleta. & $\begin{array}{l}\text { Forma de cabeza de } \\
\text { caballo. }\end{array}$ & $\begin{array}{l}\text { Los fragmentos no unen. } \\
\text { Acanaladuras paralelas a } \\
\text { lo largo de la hoja. }\end{array}$ & $\begin{array}{l}\text { Anch. máx.: 6,8; Anch. } \\
\text { mín.: } 3,5 \mathrm{~cm} .\end{array}$ & No \\
\hline
\end{tabular}


AVANCE AL ESTUDIO RADIOLÓGICO DEL ARMAMENTO DE LA NECRÓPOLIS...

\begin{tabular}{|c|c|c|c|c|c|c|c|}
\hline N. ${ }^{0} \mathrm{INV}$. & SEP. & $\begin{array}{l}\text { CRONO- } \\
\text { LOGÍA }\end{array}$ & DESCRIPCIÓN & EMPUÑADURA & HOJA & MEDIDAS & $\begin{array}{l}\text { DECO- } \\
\text { RACIÓN }\end{array}$ \\
\hline $0 / 49 / 260 / 5$ & 260 & $350-300$ a.C & $\begin{array}{l}\text { Incompleta. } \\
\text { Aspecto macizo. }\end{array}$ & $\begin{array}{l}\text { Forma de cabeza de } \\
\text { caballo. }\end{array}$ & $\begin{array}{l}\text { No conserva la punta. } \\
\text { Doblada. Acanaladuras } \\
\text { indeterminadas. }\end{array}$ & $\begin{array}{l}\text { Long máx.: } 52,5 \mathrm{~cm} . ; \\
\text { Long. máx. hoja: } 42,3 \\
\text { cm.; Anch. máx.: } 7 \mathrm{~cm} . ; \\
\text { Anch. mín.: } 4 \mathrm{~cm} .\end{array}$ & Sí. \\
\hline $0 / 49 / 260 / 7$ & 260 & $350-300$ a.C & $\begin{array}{l}\text { Incompleta. } \\
\text { Aspecto estilizado. }\end{array}$ & Guardas basales. & $\begin{array}{l}\text { Cinco fragmentos que } \\
\text { unen. No conserva la } \\
\text { punta. Acanaladuras } \\
\text { indeterminadas. }\end{array}$ & $\begin{array}{l}\text { Long. máx. hoja: } 31,6 \\
\text { cm.; Anch. máx.: } 6,5 \\
\text { cm.; Anch. mín: } 3,4 \text { cm. }\end{array}$ & No \\
\hline $0 / 49 / 263 / 7$ & 263 & 400-300 a.C & $\begin{array}{l}\text { Incompleta. } \\
\text { Aspecto estilizado. }\end{array}$ & Guardas basales. & $\begin{array}{l}\text { Acanaladuras } \\
\text { indeterminadas. }\end{array}$ & $\begin{array}{l}\text { Long. máx.: } 47,8 \text { cm.; } \\
\text { Long. máx. hoja: } 43,8 \\
\text { cm.; Anch. máx.: } 5,7 \\
\text { cm.; Anch. mín.: 3,2 cm. }\end{array}$ & Sí. Exp. \\
\hline 0/49/278/1 & 278 & 150-125 a.C & $\begin{array}{l}\text { Incompleta. } \\
\text { Aspecto estilizado. }\end{array}$ & Guardas basales. & $\begin{array}{l}\text { Acanaladuras: paralelas } \\
\text { al llegar a la } \\
\text { empuñadura. }\end{array}$ & $\begin{array}{l}\text { Long. máx. conservada: } \\
37 \text { cm.; Long. máx. hoja: } \\
30,4 \text { cm.; Anch. máx.: } \\
6,4 \text { cm.; Anch. min: } 3,9 \\
\text { cm. }\end{array}$ & No \\
\hline $0 / 49 / 318 / 3$ & 318 & 225-100 a.C & $\begin{array}{l}\text { Incompleta. } \\
\text { Aspecto estilizado. }\end{array}$ & & $\begin{array}{l}\text { Dos fragmentos que } \\
\text { unen. Hoja doblada. } \\
\text { Acanaladuras } \\
\text { indeterminadas. }\end{array}$ & $\begin{array}{l}\text { Long. máx.: 46,2 cm.; } \\
\text { Anch. máx.: } 6,2 \mathrm{~cm} \text {. }\end{array}$ & No \\
\hline $0 / 49 / 335 / 3$ & 335 & 225-100 a.C & $\begin{array}{l}\text { Incompleta. } \\
\text { Aspecto macizo. }\end{array}$ & $\begin{array}{l}\text { Guardas basales y } \\
\text { dorsales. }\end{array}$ & $\begin{array}{l}\text { Tres fragmentos. } \\
\text { Doblada. Acanaladuras: } \\
\text { divergen al llegar a la } \\
\text { empuñadura. En la hoja } \\
\text { corren paralelas. }\end{array}$ & $\begin{array}{l}\text { Long. máx.: } 41,7 \text { cm.; } \\
\text { Anch. máx.: 7,8 cm.; } \\
\text { Anch. mín.: 4,6 cm. }\end{array}$ & Sí \\
\hline $0 / 49 / 353 / 7$ & 353 & Sin datos & $\begin{array}{l}\text { Incompleta. } \\
\text { Aspecto estilizado. }\end{array}$ & $\begin{array}{l}\text { Fragmento guarda } \\
\text { basal. }\end{array}$ & $\begin{array}{l}\text { Se conserva un } \\
\text { fragmento del extremo } \\
\text { proximal. Acanaladuras } \\
\text { indeterminadas. }\end{array}$ & $\begin{array}{l}\text { Long. máx.: } 49,7 \text { cm.; } \\
\text { Long. máx. hoja: } 34,1 \\
\text { cm.; Anch. máx.: } 7 \text { cm.; } \\
\text { Anch. mín.: } 4 \text { cm. }\end{array}$ & No. \\
\hline 0/49/366/5 & 366 & $250-50$ a.C & Incompleta. & $\begin{array}{l}\text { Guardas basales muy } \\
\text { deterioradas. }\end{array}$ & $\begin{array}{l}\text { Se conserva el extremo } \\
\text { proximal. Acanaladuras: } \\
\text { con reservas, divergen al } \\
\text { acercarse a la } \\
\text { empuñadura. }\end{array}$ & $\begin{array}{l}\text { Long. máx.. } 30 \mathrm{~cm} . ; \\
\text { Anch. máx.: } 6,8 \mathrm{~cm} . ; \\
\text { Anch. mín.: } 4,1 \mathrm{~cm} .\end{array}$ & Sí \\
\hline 0/49/370 & 370 & Sin datos & $\begin{array}{l}\text { Prácticamente } \\
\text { completa. }\end{array}$ & $\begin{array}{l}\text { Forma de cabeza de } \\
\text { ave. Conserva barra de } \\
\text { unión a la guarda y } \\
\text { guarda basal. }\end{array}$ & $\begin{array}{l}\text { Acanaladuras } \\
\text { indeterminadas. }\end{array}$ & $\begin{array}{l}\text { Long. máx.: } 57 \text { cm.; } \\
\text { Long. máx. hoja: } 44,5 \\
\text { cm.; Anch. máx.: } 7 \mathrm{~cm} \text {;; } \\
\text { Anch. mín.: } 4,2 \mathrm{~cm} .\end{array}$ & No \\
\hline $0 / 49 / 373 / 2$ & 373 & $350-150$ a.C & Incompleta. & $\begin{array}{l}\text { Guardas dorsales y } \\
\text { basales aunque muy } \\
\text { deterioradas. }\end{array}$ & $\begin{array}{l}\text { Dos fragmentos que no } \\
\text { unen entre sí. } \\
\text { Acanaladuras } \\
\text { indeterminadas. }\end{array}$ & & Sí \\
\hline $0749 / 376 / 2$ & 376 & 400-250 a.C & $\begin{array}{l}\text { Incompleta. } \\
\text { Aspecto estilizado. }\end{array}$ & $\begin{array}{l}\text { Fragmentos muy } \\
\text { deteriorados. }\end{array}$ & $\begin{array}{l}\text { Doblada. Le falta el } \\
\text { extremo distal. } \\
\text { Acanaladuras: corren } \\
\text { paralelas en la hoja. }\end{array}$ & $\begin{array}{l}\text { Long. máx.: } 54,8 \mathrm{~cm} \text {; } \\
\text { Anch. máx.: } 6,9 \mathrm{~cm} \text {.; } \\
\text { Anch. mín.: 4,7 cm. }\end{array}$ & No \\
\hline
\end{tabular}




\begin{tabular}{|c|c|c|c|c|c|c|c|}
\hline N. ${ }^{0}$ INV. & SEP. & $\begin{array}{l}\text { CRONO- } \\
\text { LOGÍA }\end{array}$ & DESCRIPCIÓN & EMPUÑADURA & HOJA & MEDIDAS & $\begin{array}{l}\text { DECO- } \\
\text { RACIÓN }\end{array}$ \\
\hline $0 / 49 / 386 / 4$ & 386 & 220-190 a.C & $\begin{array}{l}\text { Incompleta. } \\
\text { Aspecto más o } \\
\text { menos macizo. }\end{array}$ & & $\begin{array}{l}\text { Acanaladuras: se } \\
\text { ensanchan en la hoja. } \\
\text { Convergen en extremo } \\
\text { distal con decoración. }\end{array}$ & $\begin{array}{l}\text { Long. máx. de la hoja: } \\
49,8 \mathrm{~cm} \text {.; Anch. máx.: } \\
\text { 5,7 cm.; Anch. mín.: } 4 \\
\text { cm. }\end{array}$ & Sí \\
\hline $0 / 49 / 400 / 6$ & 400 & 400-300 a.C & $\begin{array}{l}\text { Más o menos } \\
\text { completa. Aspecto } \\
\text { más bien macizo. }\end{array}$ & $\begin{array}{l}\text { En forma de cabeza de } \\
\text { ave, con reservas. Tres } \\
\text { fragmentos y un } \\
\text { remache. }\end{array}$ & $\begin{array}{l}\text { Siete fragmentos que } \\
\text { une entre sí. } \\
\text { Acanaladuras: en la hoja } \\
\text { corren paralelas. }\end{array}$ & $\begin{array}{l}\text { Long. máx. hoja: } 53 \\
\text { cm.; Anch. máx.: 7,3 } \\
\text { cm.; Anch. mín.: 4,2 cm. }\end{array}$ & No \\
\hline 0/49/409/4 & 409 & 375-340 a.C & Incompleta. & & $\begin{array}{l}\text { Doblada. Acanaladuras: } \\
\text { con reservas paralelas en } \\
\text { la hoja. Convergen en } \\
\text { extremo distal con } \\
\text { decoración. }\end{array}$ & $\begin{array}{l}\text { Long. máx.: } 72 \text { cm.; } \\
\text { Long. máx. hoja: } 60 \\
\text { cm.; Anch. máx.: } 6,4 \\
\text { cm.; Anch. mín.: } 4,4 \mathrm{~cm} \text {. }\end{array}$ & Sí \\
\hline $0 / 49 / 428 / 3$ & 428 & Sin datos & $\begin{array}{l}\text { Incompleta. } \\
\text { Aspecto macizo. }\end{array}$ & $\begin{array}{l}\text { En forma de cabeza de } \\
\text { ave. Conserva la barra } \\
\text { de unión a la guarda y } \\
\text { las guardas basales. }\end{array}$ & $\begin{array}{l}\text { Doblada. Acanaladuras } \\
\text { indeterminadas. }\end{array}$ & $\begin{array}{l}\text { Anch. máx.: } 6,8 \mathrm{~cm} . \\
\text { Anch. mín: } 3,9 \mathrm{~cm} \text {. }\end{array}$ & No \\
\hline $0 / 49 / 431 / 1$ & 431 & Sin datos & $\begin{array}{l}\text { Prácticamente } \\
\text { completa. Aspecto } \\
\text { estilizado. }\end{array}$ & $\begin{array}{l}\text { En forma de cabeza de } \\
\text { ave. Fragmentada en } \\
\text { cuatro partes. Guardas } \\
\text { basales. }\end{array}$ & $\begin{array}{l}\text { Tres fragmentos. Falta el } \\
\text { extremo proximal. } \\
\text { Acanaladuras } \\
\text { indeterminadas. }\end{array}$ & $\begin{array}{l}\text { Long. máx.: } 59,3 \text { cm.; } \\
\text { Long. máx. hoja: 45,5 } \\
\text { cm.; Anch. máx.: 6,6 } \\
\text { cm.; Anch. mín.: } 3,9 \mathrm{~cm} \text {. }\end{array}$ & No \\
\hline $0 / 49 / 441 / 1$ & 441 & Sin datos & Incompleta. & & $\begin{array}{l}\text { Acanaladuras } \\
\text { indeterminadas. }\end{array}$ & $\begin{array}{l}\text { Long. máx.: 24,5 cm.; } \\
\text { Anch. máx.; } 6,1 \mathrm{~cm} \text {; } \\
\text { Anch. mín: 4,1 cm. }\end{array}$ & No \\
\hline $0 / 49 / 442 / 2$ & 442 & Sin datos & $\begin{array}{l}\text { Prácticamente } \\
\text { completa. Aspecto } \\
\text { macizo. }\end{array}$ & $\begin{array}{l}\text { En forma de cabeza de } \\
\text { caballo. La cabeza } \\
\text { está soldada a la } \\
\text { guarda por una barra } \\
\text { maciza. }\end{array}$ & $\begin{array}{l}\text { Falta el extremo distal. } \\
\text { Acanaladuras } \\
\text { indeterminadas. }\end{array}$ & $\begin{array}{l}\text { Long. máx.: 60,2 cm.; } \\
\text { Long. máx. hoja: } 49,4 \\
\text { cm.; Anch. máx.: } 7 \mathrm{~cm} \text {.; } \\
\text { Anch. mín.: } 4,2 \mathrm{~cm} .\end{array}$ & No. \\
\hline 0/49/448/1 & 448 & Sin datos & $\begin{array}{l}\text { Prácticamente } \\
\text { completa. Aspecto } \\
\text { macizo. }\end{array}$ & $\begin{array}{l}\text { En forma de cabeza de } \\
\text { caballo. Cabeza } \\
\text { soldada a la guarda } \\
\text { por una barra maciza. }\end{array}$ & $\begin{array}{l}\text { Falta el extremo distal y } \\
\text { un fragmento } \\
\text { intermedio. } \\
\text { Acanaladuras: con } \\
\text { reservas divergen al } \\
\text { llegar a la empuñadura. }\end{array}$ & $\begin{array}{l}\text { Long. total: } 62,5 \mathrm{~cm} . ; \\
\text { Long. máx. hoja: } 51,4 \\
\text { cm.; Anch. máx.: 7,4 } \\
\text { cm.; Anch. mín.: } 4,6 \mathrm{~cm} \text {. }\end{array}$ & Sí. \\
\hline $0 / 49 / 450 / 1$ & 450 & Sin datos & $\begin{array}{l}\text { Completa. Aspecto } \\
\text { estilizado. }\end{array}$ & $\begin{array}{l}\text { En forma de cabeza de } \\
\text { ave. }\end{array}$ & $\begin{array}{l}\text { Acanaladuras corren } \\
\text { paralelas en la hoja. }\end{array}$ & $\begin{array}{l}\text { Long. máx.: } 55,2 \mathrm{~cm} . ; \\
\text { Long. total hoja: } 48 \mathrm{~cm} \text {;; } \\
\text { Anch. máx.: } 6,3 \mathrm{~cm} . ; \\
\text { Anch. mín.: } 4 \mathrm{~cm} .\end{array}$ & No \\
\hline $0 / 452 / 1$ & 452 & Sin datos & Incompleta. & & $\begin{array}{l}\text { Acanaladuras } \\
\text { indeterminadas. }\end{array}$ & $\begin{array}{l}\text { Long. máx. conservada: } \\
38,6 \mathrm{~cm} \text {.; Anch. máx.: } \\
5,6 \mathrm{~cm} \text {. }\end{array}$ & No \\
\hline $0 / 453 / 7$ & 453 & 325-225 a.C & $\begin{array}{l}\text { Incompleta. } \\
\text { Aspecto estilizado. }\end{array}$ & $\begin{array}{l}\text { Se conserva la guarda } \\
\text { basal. }\end{array}$ & $\begin{array}{l}\text { Acanaladuras: corren } \\
\text { paralelas en la hoja. }\end{array}$ & $\begin{array}{l}\text { Long. máx.: 39,7 cm.; } \\
\text { Anch. máx.: 6,4 cm.; } \\
\text { Anch. min.: } 3,8 \mathrm{~cm} \text {. }\end{array}$ & $\mathrm{Si}$ \\
\hline $0 / 472 / 6$ & 472 & 150-100 a.C & $\begin{array}{l}\text { Incompleta. } \\
\text { Aspecto estilizado. }\end{array}$ & & $\begin{array}{l}\text { Acanaladuras } \\
\text { indeterminadas. }\end{array}$ & $\begin{array}{l}\text { Long. máx.: 38,9 cm.; } \\
\text { Anch. máx.: 6,4 cm.; } \\
\text { Anch. mín.: } 3,7 \mathrm{~cm} \text {. }\end{array}$ & №. Exp. \\
\hline
\end{tabular}


AVANCE AL ESTUDIO RADIOLÓGICO DEL ARMAMENTO DE LA NECRÓPOLIS...

\begin{tabular}{|c|c|c|c|c|c|c|c|}
\hline N. ${ }^{0} \mathrm{INV}$. & SEP. & $\begin{array}{l}\text { CRONO- } \\
\text { LOGÍA }\end{array}$ & DESCRIPCIÓN & EMPUÑADURA & HOJA & MEDIDAS & $\begin{array}{l}\text { DECO- } \\
\text { RACIÓN }\end{array}$ \\
\hline 0/49/477/11 & 477 & 400-280 a.C & $\begin{array}{l}\text { Incompleta. } \\
\text { Aspecto más o } \\
\text { menos estilizado. }\end{array}$ & Guarda basal. & $\begin{array}{l}\text { Acanaladuras } \\
\text { indeterminadas. }\end{array}$ & $\begin{array}{l}\text { Long. máx. conservada: } \\
37 \text { cm.; Long. máx. hoja: } \\
25 \text { cm.; Anch. máx.: 5,5 } \\
\text { cm.; Anch. mín.: 3,6 cm. }\end{array}$ & No. \\
\hline $\begin{array}{c}1989 / 69 / \mathrm{G}- \\
12 / 249\end{array}$ & 597 & 400-300 a.C & $\begin{array}{l}\text { Completa. } \\
\text { Aspecto más 0 } \\
\text { menos estilizado. }\end{array}$ & $\begin{array}{l}\text { Forma de cabeza de } \\
\text { caballo. }\end{array}$ & $\begin{array}{l}\text { Acanaladuras: } \\
\text { divergen al llegar a la } \\
\text { empuñadura. }\end{array}$ & $\begin{array}{l}\text { Long. máx. conservada: } \\
62,7 \text { cm.; Long. máx. de } \\
\text { la hoja: } 52,9 \text { cm.; Anch. } \\
\text { máx. de la hoja: } 6,3 \mathrm{~cm} \text {.; } \\
\text { Anch. mín.: } 3,9 \mathrm{~cm} .\end{array}$ & Sí \\
\hline $\begin{array}{l}93 / 42 / \mathrm{H}- \\
25 / 1007\end{array}$ & 607 & 400-350 a.C & Completa. & $\begin{array}{l}\text { Forma de cabeza de } \\
\text { ave. Tres remaches. } \\
\text { Conserva guarda } \\
\text { basal y dorsal. }\end{array}$ & $\begin{array}{l}\text { Doblada por la mitad. } \\
\text { Acanaladuras: } \\
\text { divergen al llegar a la } \\
\text { empuñadura. }\end{array}$ & $\begin{array}{l}\text { Long. máx.: } 60,6 \text { cm.; } \\
\text { Long. máx. hoja: 48,3 } \\
\text { cm.; Anch. máx.: } 6,1 \\
\text { cm.; Anch. mín.: } 3,9 \mathrm{~cm} \text {. }\end{array}$ & No \\
\hline $\begin{array}{l}93 / 42 / I- \\
27 / 1024\end{array}$ & 608 & 400-300 a.C & $\begin{array}{l}\text { Completa. } \\
\text { Aspecto macizo. }\end{array}$ & $\begin{array}{l}\text { Forma de cabeza de } \\
\text { caballo. Cinco } \\
\text { remaches. Guarda } \\
\text { lateral es barra de } \\
\text { hierro. }\end{array}$ & $\begin{array}{l}\text { Doblada en el extremo } \\
\text { distal. Acanaladuras: } \\
\text { divergen al llegar a la } \\
\text { empuñadura. }\end{array}$ & $\begin{array}{l}\text { Long. máx.: } 56 \mathrm{~cm} \text {; } \\
\text { Long. máx.: } 45,8 \mathrm{~cm} \text {; } \\
\text { Anch. máx.: 5,9 cm.; } \\
\text { Anch. mín.: } 3,1 \mathrm{~cm} \text {. }\end{array}$ & Sí \\
\hline Indeterminada & & Sin datos & $\begin{array}{l}\text { Completa. } \\
\text { Aspecto } \\
\text { estilizado. }\end{array}$ & $\begin{array}{l}\text { Forma de cabeza de } \\
\text { caballo. Conserva } \\
\text { remaches. }\end{array}$ & $\begin{array}{l}\text { Doblada por la mitad. } \\
\text { Acanaladuras: } \\
\text { paralelas al llegar a la } \\
\text { empuñadura. }\end{array}$ & $\begin{array}{l}\text { Long. máx.: } 54,2 \mathrm{~cm} \text {; } \\
\text { Anch. máx.: } 5,3 \mathrm{~cm} \text {; } \\
\text { Anch. mín: } 3 \mathrm{~cm} \text {. }\end{array}$ & No. Exp. \\
\hline
\end{tabular}

Tabla 1: Falcatas hoy conservadas en el Museo de Murcia procedentes del Cabecico del Tesoro. No se incluyen las catalogadas por F. Quesada (1997) a partir de diarios o fotos o dibujos originales que no se han conservado en el Museo.

De las 609 tumbas que se conocen procedentes del Cabecico del Tesoro y tras el estudio de los fondos documentales y materiales con los que hoy contamos, se han catalogado un conjunto de 36 enterramientos que presenten falcatas entre sus elementos de ajuar, con 37 item., ya que la tumba 260 proporcionó dos. Otra falcata, de origen indeterminado dentro de la necrópolis, se encuentra descontextualizada y es imposible adscribirla a sepultura alguna. Se trata en su totalidad de enterramientos de incineración y de cronología comprendida entre el siglo IV y el II a. C. En definitiva, disponemos de una base de 38 falcatas (37 tumbas) lo que supone un porcentaje medio-bajo al compararlo con el número de sepulturas que contenían armas. En efecto 129 ajuares de Cabecico han proporcionado elementos de panoplia (Quesada Sanz, 1989(I): 143-154; García Cano, 2006 e.p.) de los que casi la mitad contuvieron falcatas, aunque el número actual de item conservados ronda el $30 \%$ del inicial.

Como se ha mencionado anteriormente, el yacimiento carece de una estratigrafía y de un estudio global con análisis de muestras, por lo que hoy sólo es posible una cronología relativa gracias a la ya tradicional, aunque efectiva, datación a través de determinados elementos de ajuar ${ }^{7}$.

7 Muñoz Amilibia, 1963; Sanmartí Grego, 1973; Poyato Holgado, 1975; Cuadrado Díaz, 1978; Morel, 1980; id., 1981; Aranegui Gascó y Pla Ballester, 1981; García Cano, 1982; Iniesta Sanmartín, 1983; Page del Pozo, 1984, entre otros. 
Nos parece interesante resaltar una serie de aspectos generales que vienen motivados por el estudio de los ejemplares conservados y por las publicaciones que se conocen para la necrópolis sobre estos artefactos. En su trabajo sobre el armamento de la necrópolis del Cabecico del Tesoro, Fernando Quesada recoge cincuenta tumbas con falcatas (1989). En nuestro caso, hemos partido únicamente del estudio directo de las falcatas conservadas en las colecciones del Museo Arqueológico de Murcia y que suponen un lote total de treinta y ocho falcatas. Además, en este punto hay que reseñar que durante las investigaciones realizadas por uno de nosotros (J.M. García Cano) en la necrópolis de Cabecico, se han exhumado tres nuevas falcatas -tumbas 597, 607 y 608- (García Cano, 2006 e.p.). Es decir, que de las falcatas catalogadas por el Doctor Quesada únicamente treinta y tres se han preservado en el Museo Arqueológico de Murcia, lo que nos lleva a pensar que probablemente algunas de ellas ni siquiera se recogieran en el momento del hallazgo, aunque fueran anotadas en los diarios en muchos casos, con la denominación de «falcata destruida». También en la década de los treinta del siglo pasado, cuando la necrópolis estaba en proceso de excavación, algunos materiales fueron trasladados a Valladolid donde iban a ser restaurados, gracias a las recomendaciones de Cayetano de Mergelina, coodirector de las excavaciones y, por aquel entonces, catedrático de Arqueología de la Universidad de Valladolid. Es posible que ciertas ejemplares desaparecieran en el trayecto aunque actualmente, y con la documentación disponible, no sabemos si los metales fueron efectivamente trasladados. Y esto nos parece una argumentación plausible para explicar la ausencia de los ejemplares descritos en las memorias de excavación, sobre todo si tenemos en cuenta que en los inventarios realizados por Manuel Jorge Aragoneses y Matilde Escortell, en la década de los sesenta aparecen citados y fotografiados únicamente las piezas que físicamente hoy se encuentran depositados en el Museo Arqueológico de Murcia.

En la gran mayoría de los casos, es difícil encontrar ejemplares completos aunque disponemos de los casos de las tumbas -263, 370, 400, 431, 442, 448 y 450 e indeterminadosiendo las números 597, 607 y 608 las que mejor se han preservado (García Cano, 2006 e. p). Por regla general los fragmentos pertenecen a la hoja en su unión con la empuñadura y a la mitad inferior de la misma donde se produce el ensanche.

De la empuñadura, se ha mantenido fundamentalmente la guarda basal, aunque con pérdida importante de grosor lo que conlleva que en algunos casos hayan desaparecido posibles elementos decorativos. Existen un total de dieciséis falcatas que conservan completa la empuñadura a falta de remaches u otros elementos como las guardas laterales. De ellos, diez ítems tienen forma de cabeza de caballo -sepulturas 183, 190 (con reservas), 198, 258, 260/5, 442, 448, 597, 608 e indeterminada- y seis tienen forma de cabeza de ave -tumbas 370, 400, 428, 431, 450, 607-. Es dificil plantear una agrupación cronológica en función del tipo de empunadura, ya que todas las falcatas mencionadas con anterioridad, a excepción de las que no hemos podido datar y el ejemplar de la sepultura 428 que se fecha en el siglo III, las encuadramos en el siglo IV a. C.

De la hoja, reseñaremos que, en un alto porcentaje de las mismas, no están completas, por lo que todas las valoraciones que se puedan hacer al respecto están en gran medida limitadas. En general, y manteniendo las clasificaciones establecidas por Fernando Quesada (1988: 278), apuntaremos, a tenor de los fragmentos analizados, que las acanaladuras cercanas a la empuñadura son del tipo C1 de Quesada Sanz, es decir las que divergen al llegar a la empuñadura, son las más frecuentes, habiéndose documentado en las falcatas pertenecientes a las tumbas 160, 198, 335, 366, 448, 597, 607, y 608 mientras que las que llegan paralelas a la empuñadura (C2 de Quesada) se han recogido únicamente en dos ejemplares -tumba 278 e indeterminada-. En relación a las acanaladuras dispuestas en el centro de la hoja y, dado el estado fragmentario y el alto grado de corrosión que presentan, ha sido imposible realizar una valoración precisa en la mayoría de los casos aunque por lo general corren 
paralelas en la hoja -salvo la de la sepultura 386 donde parece claro que se ensanchan-. Igualmente hemos documentado la convergencia al acercarse al extremo distal o inferior de la hoja, donde en más de un ejemplo la línea convergente coincide, como veremos posteriormente, con un motivo decorativo -falcatas de las tumbas 198, 386 y 409-. De manera que vuelve a ser imposible vincular los distintos tipos de acanaladuras con un marco cronológico específico.

Por lo tanto, y habida cuenta de estos elementos que, con alguna posibilidad, nos hubieran podido ofrecer un balance cronológico, no ha podido establecerse una lógica o razón en este sentido basándonos en el análisis morfológico, por lo que habría que corroborar la argumentación de Fernando Quesada cuando expresa que desde el momento en que la falcata es adoptada como arma, sus características formales están ya plenamente definidas, y desarrolladas las distintas opciones disponibles en la forma de la empuñadura o de las acanaladuras. (Quesada Sanz, 1988:285).

\section{FALCATAS CON DECORACIÓN DAMASQUINADA}

Ya indicamos anteriormente, que la mayoría de las falcatas se encuentran en mal estado de conservación con un alto grado de corrosión, carencias importantes por la exfoliación del metal y estado mayoritariamente fragmentario, hecho que hace complicada y en algunos casos ardua su lectura. Atendiendo a todo lo dicho, hemos realizado radiografías sobre 22 unidades donde se podía intervenir con ciertas garantías, es decir, mantenían restos suficientes de empuñadura, guardas u hoja. Desechando los 16 item. más desgastados, el resultado ha sido excelente, con la constatación de decoraciones en 13 falcatas, pertenecientes a los ajuares de las tumbas: 160, 198, 260, 263, 335, 366, 373, 386, 409, 448, 453, 597 y 608 . Es decir, un $325 \%$ con relación a los resultados obtenidos mediante un estudio tradicional, donde solamente observamos decoraciones en 4 item. 260, 335, 373 y 409 (Quesada Sanz, 1989 (I): 268) ${ }^{8}$.

Estos datos ponen de manifiesto que en el Cabecico del Tesoro, si nos atenemos a los materiales cuyo estado de conservación permite un análisis técnico, 22 item., apreciamos como las decoraciones en las armas llegan hasta el 59\% de las piezas. Por tanto podemos pensar que una mayoría de las falcatas estuvieron decoradas más o menos ricamente, lo que cambia sustancialmente el panorama tradicional, donde apenas unos cuantos ejemplares, algunos de ellos excepcionales, figuraban catalogados como decorados y abre una nueva parcela en el estudio del armamento ibérico. Es obvio que poco a poco y en la medida de las posibilidades presupuestarias habrá que abordar el estudio radiológico completo de los grandes conjuntos ibéricos murcianos como Coimbra del Barranco Ancho (Jumilla), Cigarralejo (Mula), Los Nietos (Cartagena), Castillejo de los Baños (Fortuna) y La Albufereta (Alicante) entre otros, porque los resultados serán sin duda espectaculares ${ }^{9}$.

Los ornamentos, siempre teniendo en cuenta los fragmentos conservados de cada ejemplar -aparece en la empuñadura- 260, 335, 373 y 608 -en la hoja- 160, 198, 263, 366, 386, 409 y 453 -o en ambas partes- 448 y 597 . En la empuñadura, los lugares más comunes son las guardas basales y dorsales aunque en algún caso -falcata de la sepultura 597- se han con-

${ }^{8}$ La falcata del ajuar 350 es realidad de la tumba 373. Véase la justificación y análisis de dicha falcata en el catálogo.

9 En este punto hay que decir que en reflexiones particulares mantenidas con otros especialistas como Fernando Quesada, Emeterio Cuadrado o Virginia Page siempre habíamos considerado que el número de armas decoradas, no solo las falcatas, tendría que ser mucho mayor que el volumen que eramos capaces de apreciar a simple vista. Aunque quizás no pensasemos que el número iba a ser tan alto como los resultados que ha proporcionado el presente estudio. 
servado damasquinados en la guarda lateral. Para la hoja, la decoración se inscribe a la divergencia de las acanaladuras en la zona más cercana a la empuñadura -como en el caso de los números 198, 386, 597- o bien a lo largo de las acanaladuras paralelas al filo dorsal -números 263, 597, 453 y al lugar donde convergen las acanaladuras, adoptando en esta ocasión esa misma forma en muchas ocasiones- números 160, 198, 386, 409, 448, 453. Casos aislados lo constituyen las falcatas de las sepulturas 366, donde la decoración aparece en la hoja, en la parte cercana a la empuñadura aunque dispuesta de forma paralela a la guarda basal y el elemento decorativo zoomorfo de la falcata número 597, que aparece al finalizar la cenefa que corre paralela al filo dorsal. También aquí la decoración de la parte inferior de la hoja aparece en paralelo al filo dorsal del arma.

Los motivos decorativos examinados son de manera mayoritaria vegetales y geométricos, perfectamente insertos en la tabla propuesta por Fernando Quesada hace unos años (1997(I):121, figura 66). Sin embargo, hemos de confirmar que han aparecido variantes, subtipos y sobre todo algunos nuevos modelos, pensamos que de gran importancia, belleza y valor simbólico que permitirán adentrarnos todavía más en el conocimiento de las creencias y la iconografía de las sociedades ibéricas.

Los adornos generales comunes a las falcatas de Cabecico son ornatos geométricos a base de dientes de lobo, espirales o róleos y líneas quebradas números 260, 263, 366, 409, 453 o 597. A estos hay que añadir los atavíos compuestos por hojas de hiedra entrelazadas de distinta calidad, como puede apreciarse en los ejemplares de las tumbas 160, 335 y especialmente, en la que lleva la hoja de la falcata de la tumba 409. En este caso se trata de hojas de gran tamaño, muy estilizadas unidas por tallos que le confieren al conjunto una gran solidez y calidad indudable. Otra ornamentación genérica, por lo general ornando las cartelas de la guarda basal son los motivos de palmetas de cuenco más o menos elaboradas y en distinto grado de conservación de las tumbas 335 y 373. También dispuesto en la guarda basal se ha catalogado un dibujo de ovas enfrentadas (T.608).

Las decoraciones de gran desarrollo reservadas para las hojas han sido las de una gran palmeta con componentes de carácter geométrico/vegetal con hojas de hiedra, zarcillos entrelazados, róleos y/o liras estilizadas que sirven de base a sendas hileras confeccionadas con espirales/róleos que se abren desde la palmeta a lo largo de la hoja y que en ciertos casos, parecen rematarse en una cabeza de cánido con la lengua colgando (T.198). En esta situación tendríamos ejemplares de las tumbas 160, 198, 386, 448 y 453.

Por último hacer referencia a la ornamentación de tres falcatas donde los temas propuestos tuvieron una plasmación zoomorfa. En dos de los casos contamos con la presencia de jabalíes; uno decora la guarda basal del item de la tumba 260 y ya fue publicado por F. Quesada (1989(I):269, figura 104). Aquí el jabalí parece estar en posición de carga y se integra a la perfección con el resto de la decoración geométrica circundante. Los análisis radiológicos han permitido descubrir en el inicio de la hoja de la falcata del ajuar 198 una espléndida escena de lucha entre un jabalí y un cánido. El tercer item con imágenes extraordinaria procede de la tumba 597. En este caso la práctica totalidad del arma ha sido damasquinada: empuñadura con las guardas basal, lateral y dorso, así como una buena proción de la hoja, de 53 centímetros de longitud, rematándose la decoración cerca de la punta. La empuñadura exhibe ornatos geométricos que se prolongan en la hoja a base de una gran franja formada por róleos y dientes de lobo. Sin embargo, al inicio de esta, junto a la guarda basal se han representado dos cabezas de cánido con las orejas tiesas unidas por la nuca mediante un pequeño conjunto de róleos a modo de dos protomos de perro. Pero destaca sobre todo el dibujo de un pez próximo a la punta, representado mediante las espinas dorsal y lateral, siluetándose el conjunto. 


\section{LA RIQUEZA Y CRONOLOGÍA DE LOS AJUARES CON FALCATAS DECORADAS}

En la exhaustiva monografía que al armamento ibérico de Cabecico del Tesoro dedicó el profesor Fernando Quesada, el valor medio general obtenido en los ajuares de la necrópolis ascendía a 4.5 puntos, 4.8 si se exceptuaban las incineraciones que no proporcionaron ajuares. No obstante el promedio alcanzado en las tumbas con armamento, según el mismo criterio, aumentaba hasta las 7.4 unidades. Como afirmaba el Dr. Quesada Sanz hay una apreciable diferencia de poder adquisitivo en los ajuares detentadores de panoplia (Quesada Sanz, 1989(I):156).

Al analizar el valor material de las tumbas ahora estudiadas (tabla 2), se infiere que la riqueza de las incineraciones con falcatas decoradas es todavía superior a la concluida por F. Quesada, es decir, la media aritmética se situa ahora en 8.7 puntos frente a los 7.4 anteriores. Este hecho pone de manifiesto la indudable pujanza de los propietarios de las tumbas con armas y dentro de las mismas las poseedoras de items decorados con bellos damasquinados de plata, que se separan todavía más del general de los enterramientos ibéricos, dejando de manifiesto la vinculación de estos magníficos items con la aristocracia dirigente. Con los datos actuales la prosperidad de los ajuares con panoplia en Cabecico del Tesoro se coloca en 8 puntos.

Hay que tener en cuenta que dos de las tumbas recogidas en este trabajo procedentes de las excavaciones sistemáticas realizadas en la necrópolis entre 1989 y 1993, n. 597 y 608, tienen ricas decoraciones damasquinadas en sus respectivas falcatas. Se pueden inscribir dentro de los ajuares funerarios más ricos superados únicamente por 5 ajuares a lo largo del siglo IV, cronología a la que pertenecen ambas; y otros 4 correspondientes a las restantes dos centuarias de ocupación de la necrópolis (Quesada Sanz, 1989(I):173-175). La 597 muestra decoración prácticamente en toda la superficie del arma destacando unos protomos de perro enfrentados en el inicio de la hoja y un singular pez, happax hasta la fecha entre los motivos decorativos ibéricos, próximo a la punta. El volumen de objetos recuperado en este ajuar asciende a 21 items.; por lo respecta a la tumba 608 tiene decorada la guarda basal con un bello motivo de ovas enfrentadas y el número de piezas registradas en el ajuar suma 27.

\begin{tabular}{|c|c|c|l|}
\hline Tumba & N. $^{\text { }}$ Objetos & Cronología & \multicolumn{1}{|c|}{ Decoración } \\
\hline 160 & 7 & $150-100$ & Gran palmeta \\
\hline 198 & 6 & $400-300$ & Jabalí-perro y gran palmeta \\
\hline 260 & 9 & $350-300$ & Jabalí. Decoración geométrica \\
\hline 263 & 11 & $400-300$ & Decoración geométrica \\
\hline 335 & 4 & $225-100$ & Palmetas cuenco. Hojas hiedra \\
\hline 366 & 7 & $200-50$ & Motivos geométricos \\
\hline 373 & 3 & $350-150$ & Palmetas de cuenco \\
\hline 386 & 5 & $220-190$ & Gran palmeta \\
\hline 409 & 4 & $375-340$ & Hojas hiedra y geométrica \\
\hline 448 & 1 & - & Gran palmeta \\
\hline 453 & 9 & $325-225$ & Gran palmeta y geométrica \\
\hline 597 & 21 & $400-300$ & Geométrica.Cánidos y pez \\
\hline 608 & 27 & $400-300$ & Motivos de ovas enfrentadas \\
\hline
\end{tabular}

TABLA 2 
Por lo que respecta al marco cronológico de las falcatas damasquinadas de Cabecico del Tesoro, hemos considerado la fecha de la incineración en el momento más bajo de la horquilla temporal que marcan los objetos del ajuar. Así, la mayoría 50\%/6 items se situan en el siglo IV antes de Cristo, - n. ${ }^{\circ} 198,260,263,409,597$ y 608-. Con una media aritmética cuyo valor es de 13.3 unidades. Es decir, un guarismo muy superior al general hallado en los ajuares con armamento 8.7 puntos.

Para el siglo III disponemos en exclusiva de una deposición -n. $.^{\circ} 453-$ que representa el $8.3 \%$ de las falcatas decoradas, datada en torno al 225 anterior a Cristo. Su índice de riqueza se establece en 9 unidades. En el siglo II tenemos 4 tumbas -160, 335, 373 y 386-que suman el $33.3 \%$ de las piezas registradas. Sin embargo en esta centuria los ajuares recuperados descienden significativamente hasta los 4.75 , casi en la media orgánica de los ajuares de Cabecico pero claramente por debajo del guarismo obtenido en las sepulturas con armas. Por último observamos una tumba -366- cuya oscilación temporal puede ir desde el 200 hasta el 50 anterior a Jesucristo, significa el $8.3 \%$ de la muestra y su valor numérico se situa en 7 puntos.

Como resumen podemos inferir que las piezas decoradas del siglo IV pertenecen a ajuares más ricos y en general muestran motivos mejor elaborados, al menos en lo que respecta a escenas con representaciones cinegéticas, es decir, la presencia de jabalíes -tumbas 198 y 260 - o jabalíes y perros -198 y 597- y la constatación de un pez (T.597) o incluso el motivo de ovas enfrentadas en la cartela de la guarda basal de la tumba 608 que puede ponerse en relación con los temas habituales que llevan las cerámicas áticas de barniz negro fabricadas entre las últimas décadas del siglo $\mathrm{V}$ y primeros años de la centuria siguiente que llegan a las poblaciones ibéricas en número significativo.

El diferencial de riqueza entre los ajuares se va acortando con el transcurso del tiempo y para el siglo III la única pieza catalogada se fecha hacia finales de la centuria. Lleva una gran palmeta de marcado carácter fitomorfo (T.453) que puede vincularse con los motivos que, en general, ofrecen algunas de las falcatas del siglo II, como las que exhiben las de las tumbas 160, 386 y 448 aunque esta última sin datación precisa. De esa cronología se ha podido catalogar otro elemento característico de amplia tradición mediterránea como son las palmetas de cuenco de las falcatas de las tumbas 335 y 373.

\section{CATÁlogo de MATERIALES}

\section{Tumba 160}

N. ${ }^{\circ}$ inventario: 0/49/160/6.

CRONOLOGÍA: 150-100 a. C.

DESCRIPCIÓN: Falcata prácticamente completa. Conservada en cuatro fragmentos que unen entre si. Tres pertenecientes a la hoja y el superior a la parte proximal de la hoja y la empuñadura.

EMPUÑADURA: Se ha preservado únicamente la guarda basal.

HOJA: Doblada intencionadamente. Tiene un aspecto bastante macizo y su longitud es media en relación a la total de la falcata.

Acanaladuras: Según el análisis realizado, divergen al acercarse al extremo cercano a la empuñadura y acaban convergiendo conforme avanza la hoja.

DECORACION: Desarrollada paralela al dorso del arma. Compuesta por dos grandes franjas oblicuas que enmarcan en su interior un motivo de espirales enlazadas contrapuestas. La unión de ambas hileras remata en una gran palmeta con hojas de hiedra y zarcillos entrelazados, que corresponde con los motivos 7-9 y 16 de Fernando Quesada (1997(I):121, figura 66).

MEDIDAS: Longitud máxima conservada: $49,8 \mathrm{~cm}$; longitud máxima de la hoja: $43,9 \mathrm{~cm}$; ancho máximo de la hoja: $6,9 \mathrm{~cm}$. está en la zona más cercana a la empuñadura; ancho mínimo: 4,8 cm. 


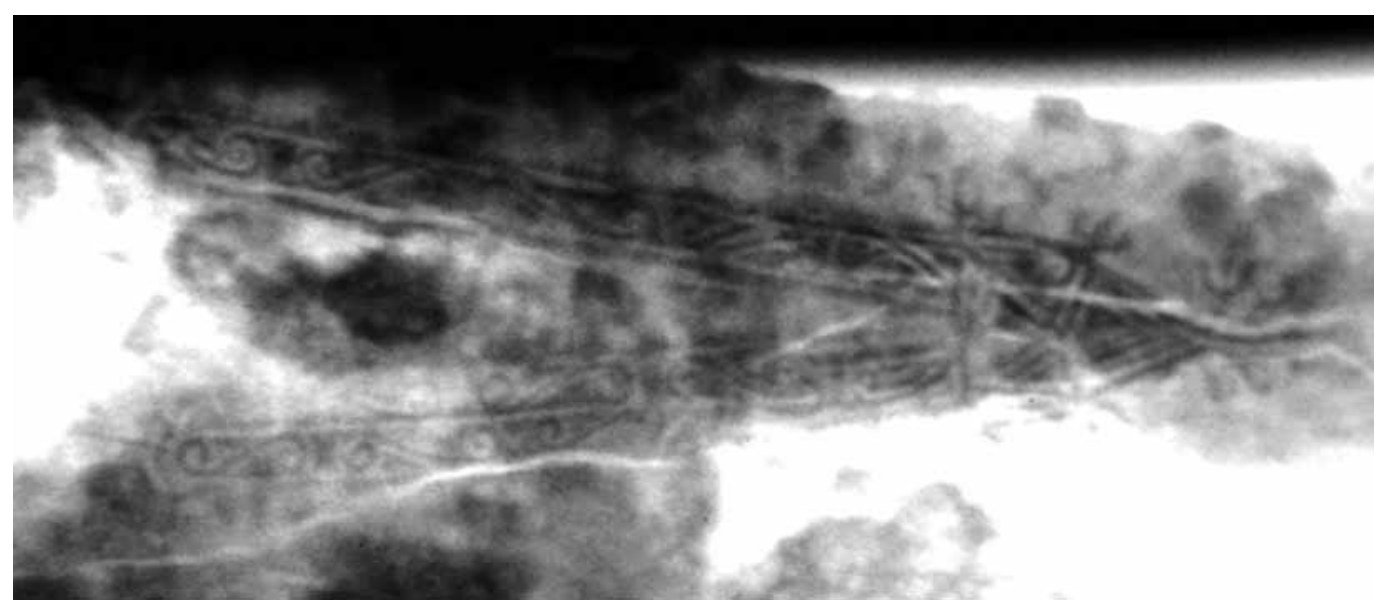

TUMBA 160

\section{Tumba 198}

N..$^{\circ}$ inventario: 0/49/198/1.

CRONOLOGÍA: 400-350 a. C.

DESCRIPCIÓN: Incompleta, en tres fragmentos, el superior unido a la guarda basal. Carece de una buena parte de la empuñadura y del extremo distal de la hoja.

EMPUÑADURA: Conserva parte de la guarda basal por ambas caras, en cuatro fragmentos.

HOJA: Tiene un aspecto macizo y hoja bastante larga. Acanaladuras: Divergen al acercarse a la empuñadura.

DECORACION: Junto al inicio de la hoja, presenta una excelente imagen de lucha entre un cánido, probablemente un lobo o un gran perro, contra un jabalí. El perro presenta las fauces abiertas en actitud amenazante, mientras que el suido con la cabeza inclinada hacia delante y las patas delanteras en posición de parada-retroceso, está presto a defenderse con la boca entreabierta mostrando de manera ostensible, sus enormes defensas.

La hoja ya próxima a la punta desarrolla un magnífico dibujo. Una enorme palmeta compuesta por espirales, roleos y liras estilizadas de la que parten dos líneas o franjas oblicuas hechas a base de espirales/roleos entrelazados que se rematan en sendas cabezas de iperro?, con la boca abierta y lengua colgando. Aunque el trazado rectilíneo y homogéneo de las franjas que culminan en un remate zoomorfo, recuerdan en un primer golpe de vista, al cuerpo de dos ofidios que nacieran del motivo fitomorfo.

El profesor Quesada Sanz ha recogido en su espléndido repertorio iconográfico cabezas y protomos de perro (Quesada Sanz, 1997(I):121, figura 66, n. ${ }^{\circ}$ 34-35). Esta representación con la boca abierta y la lengua colgando es nueva, lo mismo que la magnífica escena del cánido y el jabalí descrita en primer lugar. Fernando Quesada catalogó una escena similar ubicada también en el inicio de la hoja de la falcata donde se enfrentaban un león, en nuestro caso un perro, y un jabalí (Quesada Sanz, 1997(I):120, figura 62).

MEDIDAS: Longitud máxima conservada: $46,5 \mathrm{~cm}$; longitud conservada de la hoja: 49,3 cm; ancho máximo: $6,7 \mathrm{~cm}$. en la zona cercana a la empuñadura; ancho mínimo: 4,3 cm. 


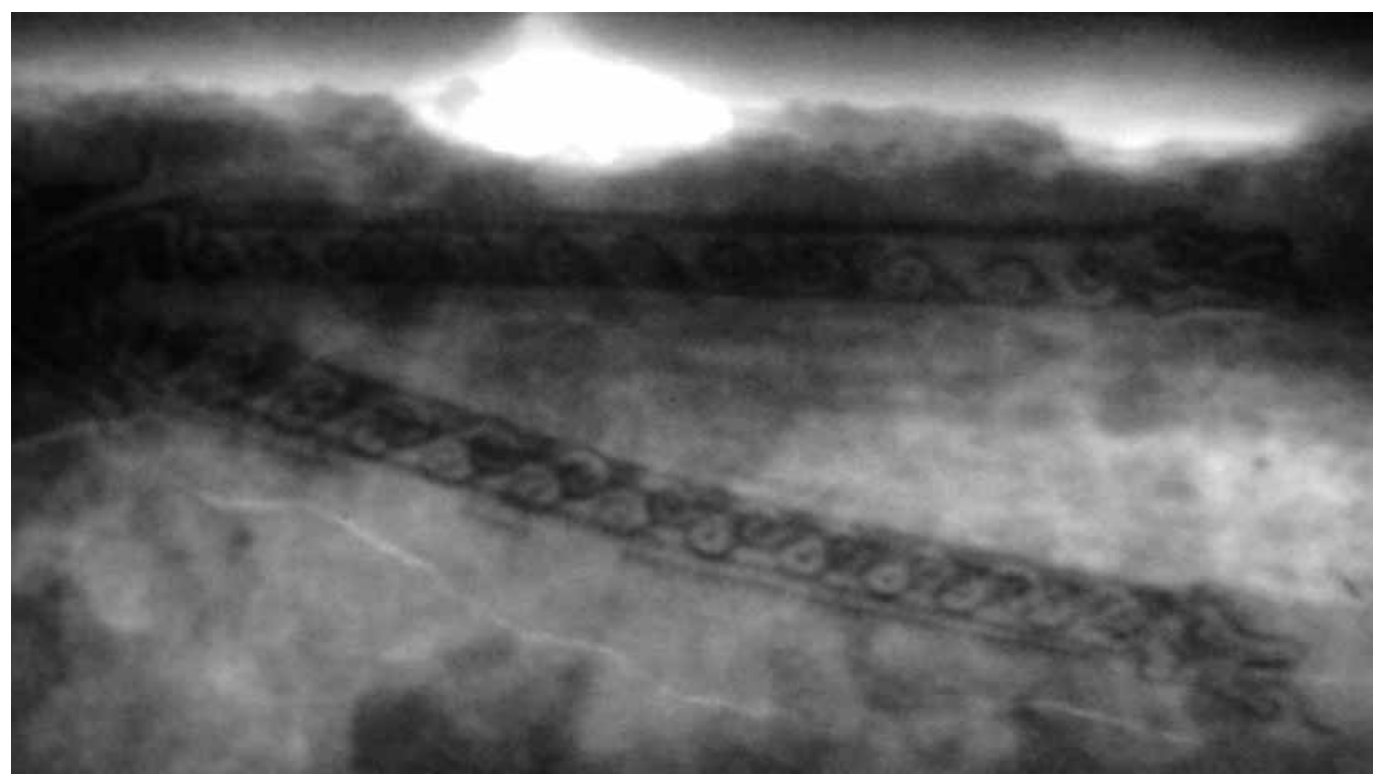

TUMBA 198

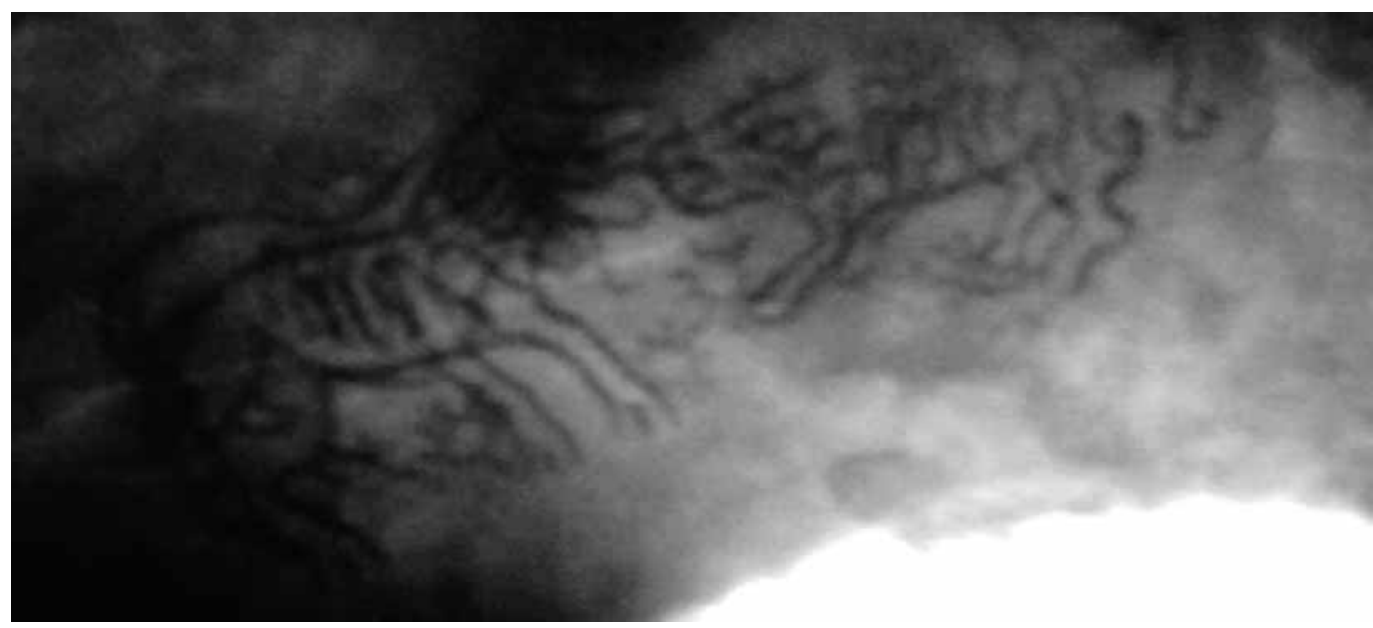

TUMBA 198

\section{Tumba 260}

N. ${ }^{\circ}$ inventario: 0/49/260/5.

CRONOLOGÍA: 350-300 a. C.

DESCRIPCIÓN: Incompleta y aparece dividida en seis fragmentos pertenecientes a la hoja y la empuñadura.

EMPUÑADURA: Ignoramos el tipo, aunque podría tratarse de forma de cabeza de caballo. Conserva tres remaches y la decoración en la guarda basal y dorsal de la empuñadura.

DECORACION: En la parte ancha de la guarda basal, presenta un magnífico jabalí cuya dibujo muestra detalles del pelaje, hocico etc. El resto de la decoración es geométrica, a base de una línea quebrada en zig-zag, enmarcados por sendas líneas, que parten del hocico del suido. La otra cara de la guarda, muy deteriorada, no llega a vislumbrarse el jabalí, pero sí las líneas quebradas que 
cubren la parte estrecha de la guarda que se corresponden con el motivo 1 de Quesada Sanz (1997(I):121, figura 66-1).

El dorso de la guarda basal aparece decorado con un gran dibujo geométrico muy deteriorado que parece estar formado por roleos/espirales entrelazadas formando como un racimo de cuatro en fondo.

HOJA: Está fragmentada en cuatro y no conserva el extremo distal. Fue doblada intencionalmente. Es bastante larga y tiene un aspecto estilizado.

Acanaladuras: Indeterminadas.

MEDIDAS: Longitud máxima: (es aproximada ya que, al haber sido doblada, puede faltar algún fragmento): $52,5 \mathrm{~cm}$; longitud máxima conservada de la hoja: $42,3 \mathrm{~cm}$; ancho máximo: $7 \mathrm{~cm}$. (en la zona cercana a la empuñadura); ancho mínimo: $4 \mathrm{~cm}$; medida empuñadura: $10,3 \mathrm{~cm}$.
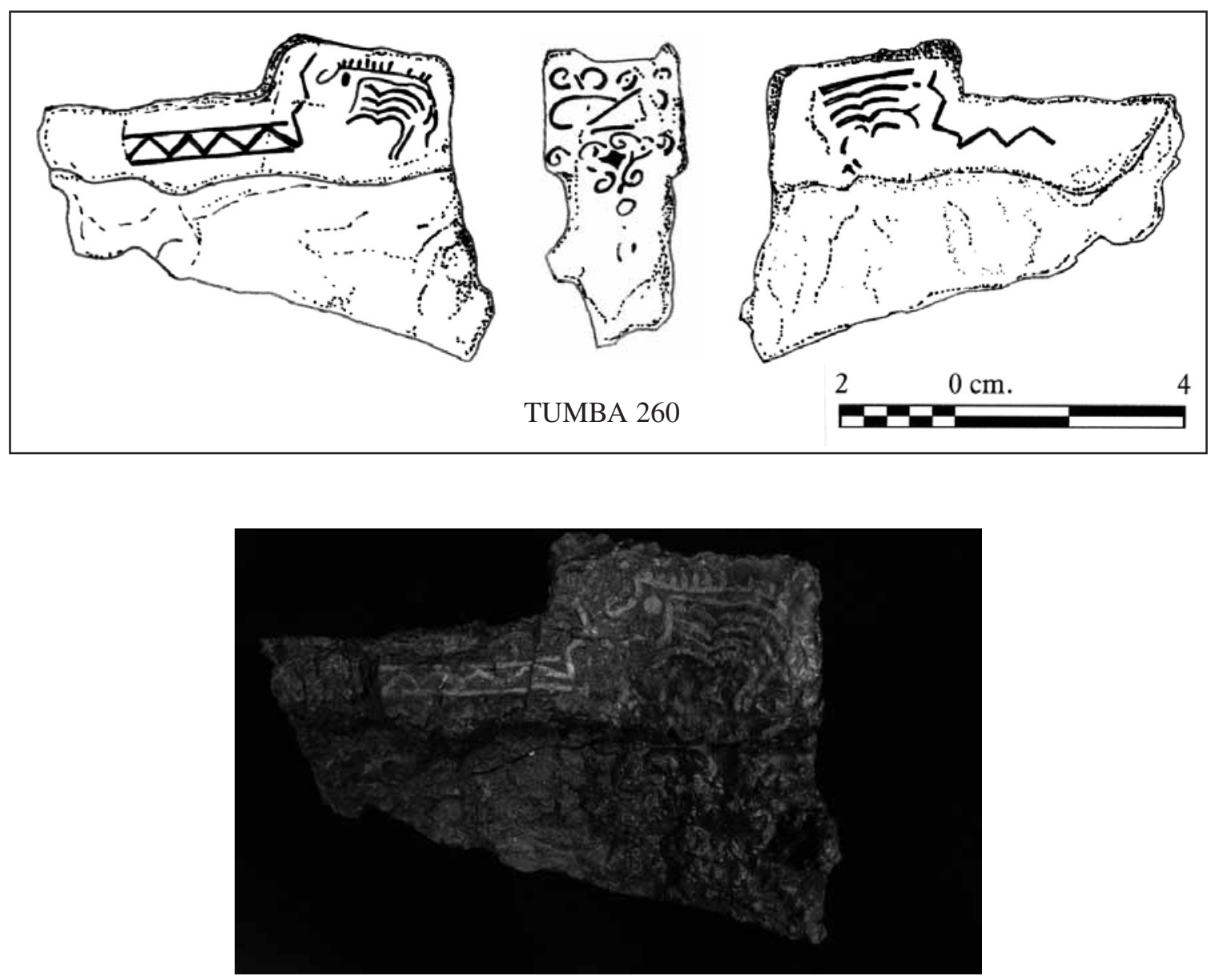

TUMBA 260

\section{Tumba 263}

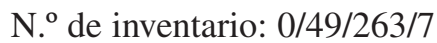

CRONOLOGÍA: 400-300 a. C

DESCRIPCIÓN: Completa y de aspecto bastante macizo.

EMPUÑADURA: Empuñadura en forma de cabeza de pájaro. Conserva la guarda basal y parte de la lateral, pero no los remaches.

HOJA: Completa. 
Acanaladuras: Indeterminadas aunque parecen correr paralelas desde el extremo cercano a la empuñadura.

DECORACION: Muestra una hilera de roleos/espirales de elaboración muy tosca junto al filo dorsal. MEDIDAS: Longitud máxima: $64 \mathrm{~cm}$; longitud máxima conservada de la hoja: $51,9 \mathrm{~cm}$; ancho máximo: 7,1 cm; ancho mínimo: $4,1 \mathrm{~cm}$

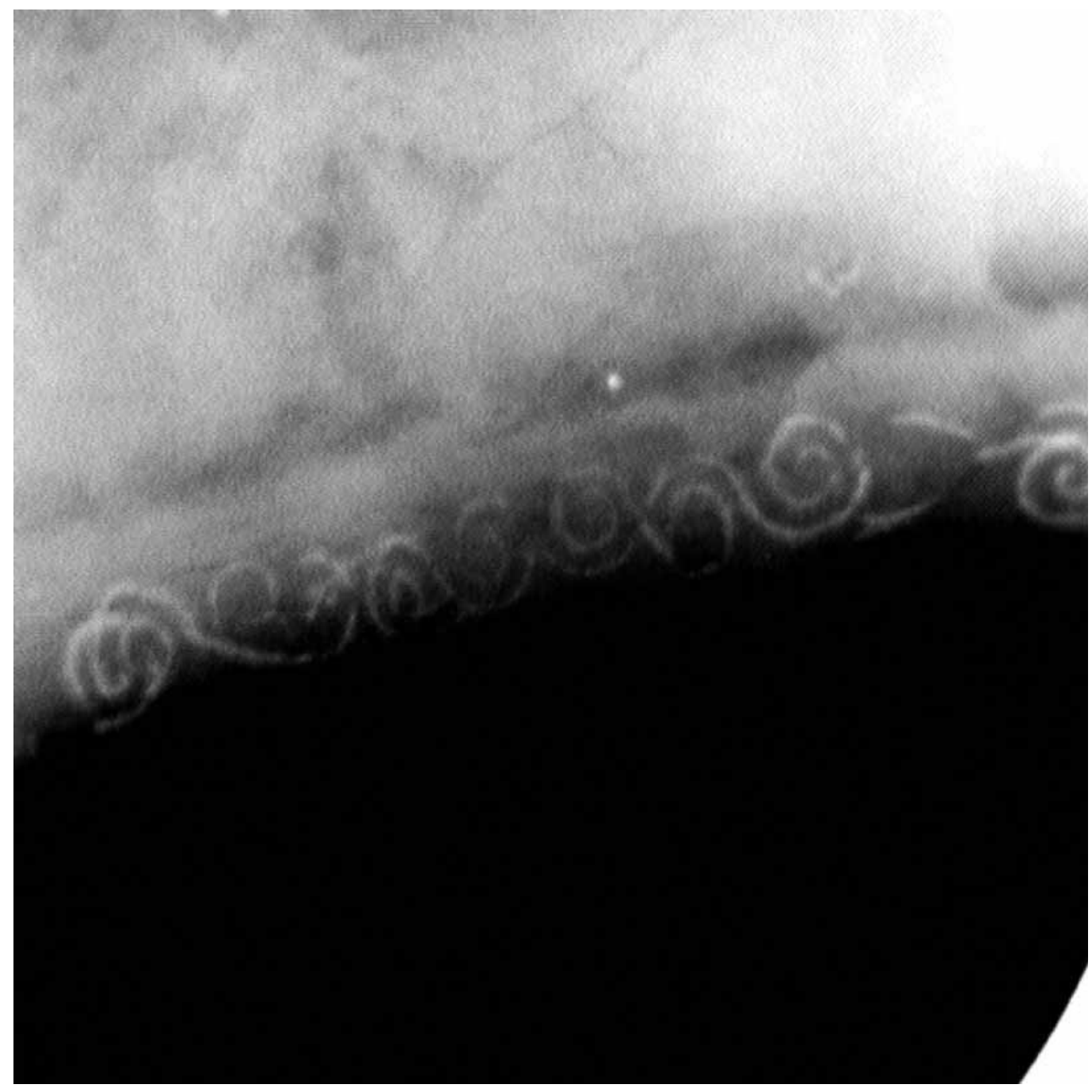

TUMBA 263

\section{Tumba 335}

N. ${ }^{\circ}$ de inventario: 0/49/335/3.

CRONOLOGÍA: 225-100 a. C.

DESCRIPCIÓN: Incompleta y fragmentada en tres partes. Dos trozos corresponden a la hoja y el tercero pertenece a la empuñadura -guarda basal- e inicio de la hoja.

EMPUÑADURA: Sólo se conserva la guarda basal y lateral.

DECORACION: Presenta en la parte ancha de la guarda basal varias palmetas de cuenco enfrentadas, y en una de las caras, el remate del motivo a base de un friso de espirales enlazadas. En la zona estrecha de la misma, lleva una interesante figura de raíz fitomorfa a base de una hilera de hojas 
de hiedra y debajo una franja de ola encrespada, donde parece que las curvas de las espirales ayudan a alinear el friso de grandes y cuidadas hojas de hiedra. En el dorso de la guarda también se aprecia otra imagen de palmetas de cuenco.

Tanto las palmetas de cuenco empleadas (n. $\left.{ }^{\circ} 23-24\right)$ como las espirales enlazadas (n. ${ }^{\circ}$ ) figuran en el catálogo de F. Quesada (1997(I):121, figura 66).

HOJA: Doblada en la mitad inferior de manera intencionada. No conserva el extremo inferior de la misma. Los fragmentos analizados indican un aspecto bastante macizo y de una longitud considerable.

Acanaladuras: Las tiene divergentes en la parte más cercana a la empuñadura, que prosiguen paralelas y finalmente convergen en el extremo inferior.

MEDIDAS: Longitud máxima conservada: (teniendo en cuenta que está doblada: 42,3 cm; longitud máxima de la hoja: $38,4 \mathrm{~cm}$; ancho máximo: $7,1 \mathrm{~cm}$; ancho mínimo: $4,2 \mathrm{~cm}$.
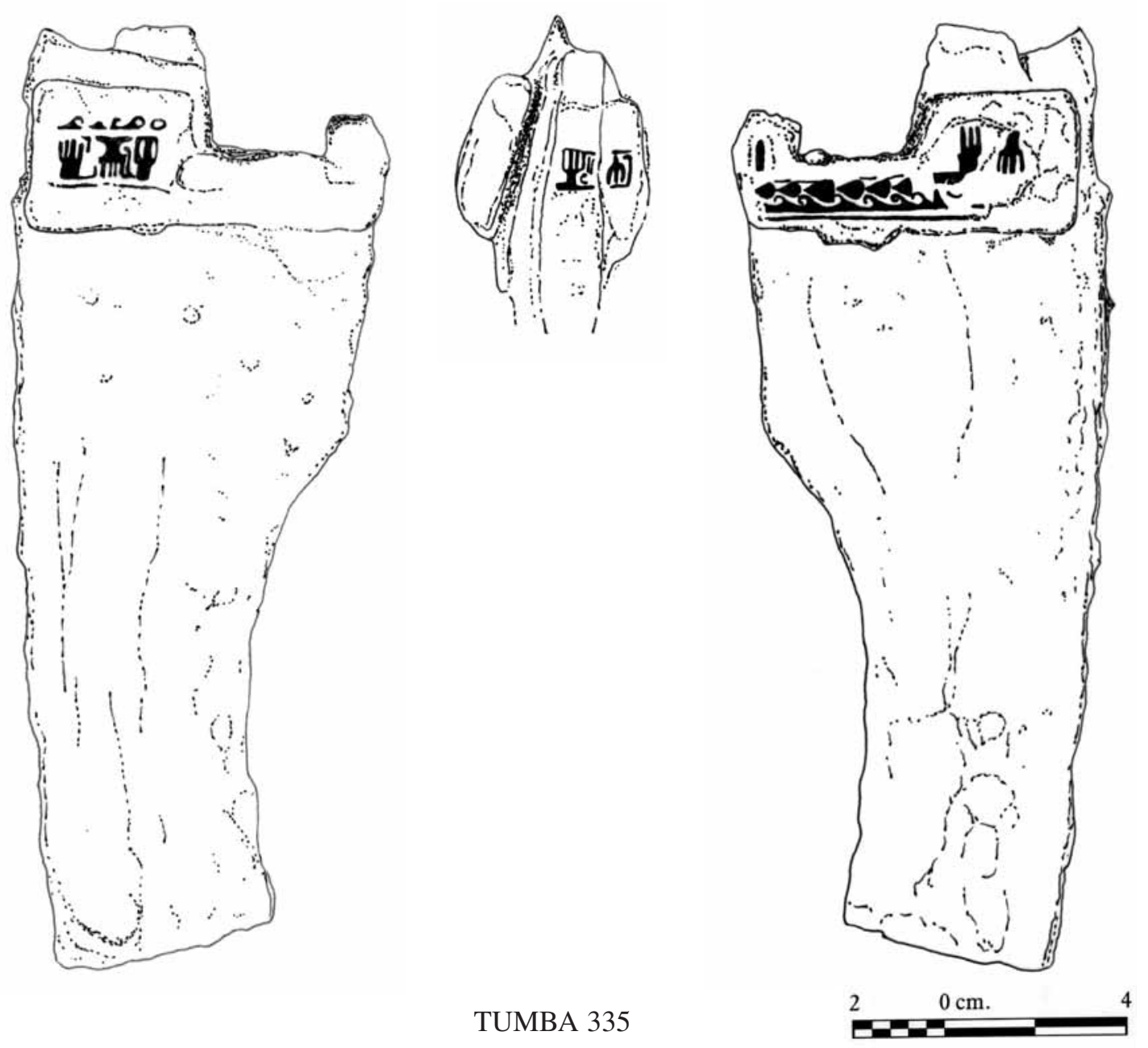

TUMBA 335 


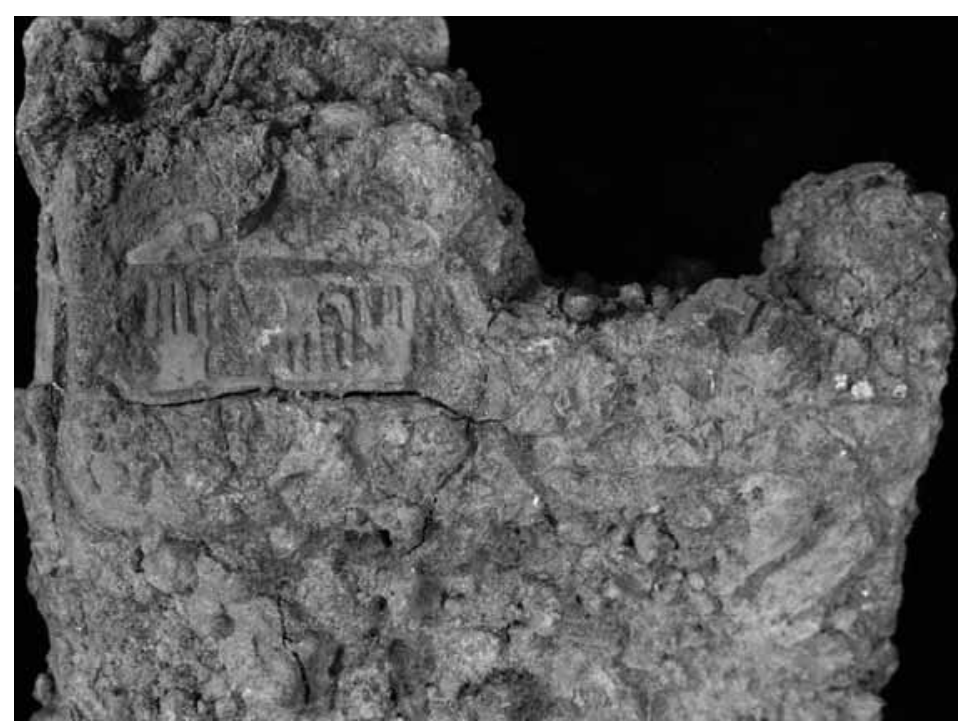

TUMBA 335

\section{Tumba 366}

N. ${ }^{\circ}$ de inventario: 0/49/366/5.

CRONOLOGÍA: 250-50 a. C.

DESCRIPCIÓN: Incompleta y muy deteriorada. Un único fragmento perteneciente a la guarda basal de la empuñadura y a la parte superior de la hoja.

EMPUÑADURA: Muy deteriorada, conserva parte de la guarda basal.

HOJA: Un solo fragmento del inicio de la hoja.

Acanaladuras: Con reservas, divergen al llegar a la empuñadura.

DECORACION: Aparece en la parte superior de la hoja, con un motivo muy peculiar en cuanto a su disposición ya que se trata de una banda de motivos geométricos que corre paralela a la guarda basal de la empuñadura. Se aprecian restos de una decoración damasquinada a base de combinaciones de espirales enlazadas.

MEDIDAS: Longitud máxima conservada: $29,2 \mathrm{~cm}$; longitud máxima de la hoja: $25,4 \mathrm{~cm}$; ancho máximo: $6,8 \mathrm{~cm}$; ancho mínimo: $3,9 \mathrm{~cm}$.

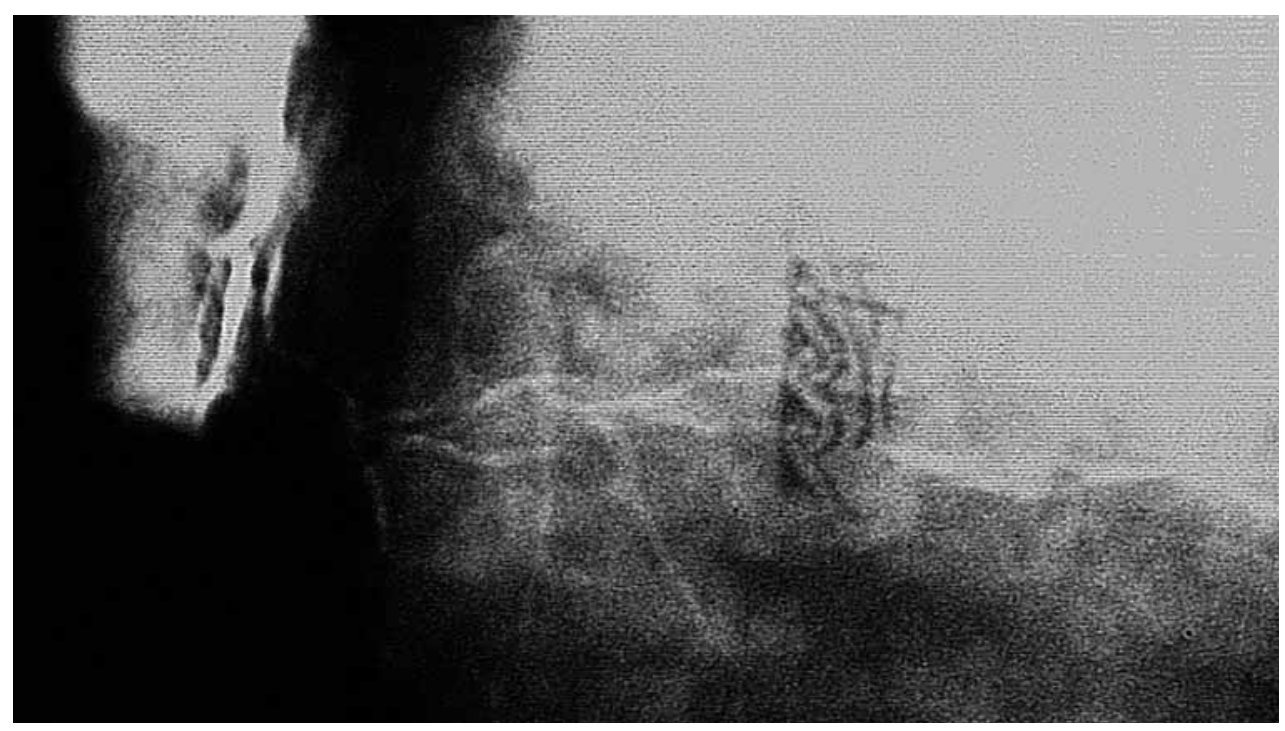

TUMBA 366 


\section{Tumba 373}

N. ${ }^{\circ}$ de inventario: 0/49/373/2

CRONOLOGÍA: $350-150$ a. C.

DESCRIPCIÓN: Incompleta que conserva dos fragmentos pertenecientes a la hoja en su extremo proximal y a parte de la empuñadura. No presenta un aspecto muy macizo.

EMPUÑADURA: Incompleta, preserva parte de la espiga y guarda basal muy deteriorada. Tiene un remache en la espiga.

DECORACION: En la guarda basal, vemos en la zona de mayor superficie restos de palmetas de cuenco enmarcadas por una franja de espirales combinadas hacia la espiga de la empuñadura, mientras que por debajo queda delimitada la escena principal por varias hileras de líneas quebradas que en la base de la guarda continúan como una orla de espirales enlazadas. En general muy deteriorada. La otra cara debió de llevar idéntica decoración: palmetas de cuenco (cartela) y líneas quebradas y orlas, pero muestra un estado lamentable. Aquí se ha preservado mejor, en el extremo, adjunto a la cara lateral (guarda lateral) la decoración. Se ha colocado la base de una palmeta, en concreto parece que las volutas terminales. La cara ventral de la guarda presenta restos damasquinados muy perdidos quizás restos de roleos contrapuestos que pudieran pertenecer a la base de dos palmetas. ${ }^{10}$

HOJA: Encontramos dos fragmentos: Uno unido a la empuñadura y otro del extremo proximal de la hoja.

Acanaladuras: El grado de corrosión que presenta la hoja y el reducido tamaño del fragmento impiden apreciar si la hoja tenía acanaladuras o no.

MEDIDAS: Longitud máxima conservada: $17,4 \mathrm{~cm}$; longitud máxima conservada de la hoja: 10,3 cm; ancho máximo: $6,1 \mathrm{~cm}$. se encuentra en la zona cercana a la empuñadura pero en realidad no se puede saber porque no hay datos suficientes; ancho mínimo: $3,1 \mathrm{~cm}$.

${ }^{10}$ En esta arma tenemos que manifestar una duda que se nos ha planteado al estudiar el conjunto de falcatas conservadas en el Museo Arqueológico de Murcia procedentes de Cabecico del Tesoro. En el completo estudio que el Dr Fernando Quesada hizo de estos items hace unos años (Quesada Sanz, 1989) se recogía en el catálogo los restos de la empuñadura de una falcata adjudicada a la tumba 350 (Quesada Sanz, 1989(II):182). Sin embargo, tanto en el ajuar de dicha tumba conservado en el Museo Arqueológico de Murcia, como en el inventario sistemático que de los materiales de la necrópolis del Cabecico se hizo en la década de los años sesenta del siglo XX no figura resto alguno de una falcata en este ajuar.

Creemos a la vista de los dibujos que aporta el propio Fernando Quesada y nuestro exhaustivo trabajo por aclarar la ubicación de todas y cada una de las armas, que el profesor Quesada Sanz debió de tener una confusión provocada quizás por la acumulación de materiales durante el estudio que lo llevaron a estudiar la empuñadura de la tumba 373 dos veces, como 373 y 350. Así, si nos fijamos en el dibujo de la supuesta tumba 350 que aporta el profesor Quesada (1989(II):182) cartela a la derecha observamos que su descripción coincide con nuestra cara A de la tumba 373, incluido el detalle de la decoración de la cara ventral de la guarda basal. Del mismo modo si analizamos el dibujo propuesto por F. Quesada para la tumba 373 (Quesada Sanz, 1989(II):189), apreciamos que coincide con el nuestro de la tumba 373 cara B.

Por tanto pensamos que se trata de una única pieza -tumba 373- y que la tergiversación pudo producirse en cualquier momento del colosal estudio que Fernando Quesada emprendió valientemente en los fondos del Museo Arqueológico de Murcia en los años ochenta enfrentándose con los 594 ajuares conservados de la necrópolis del Cabecico del Tesoro. 

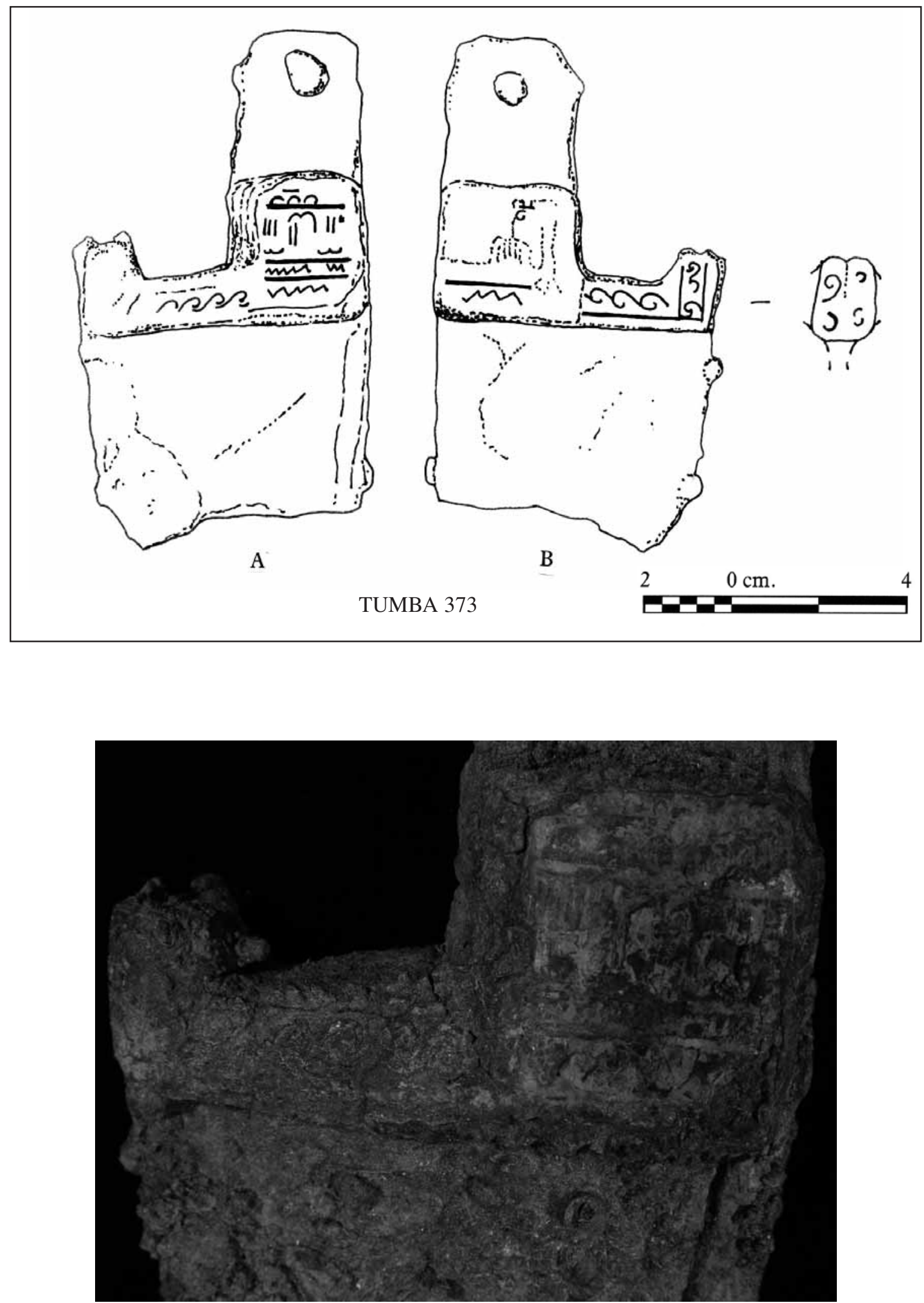

TUMBA 373 


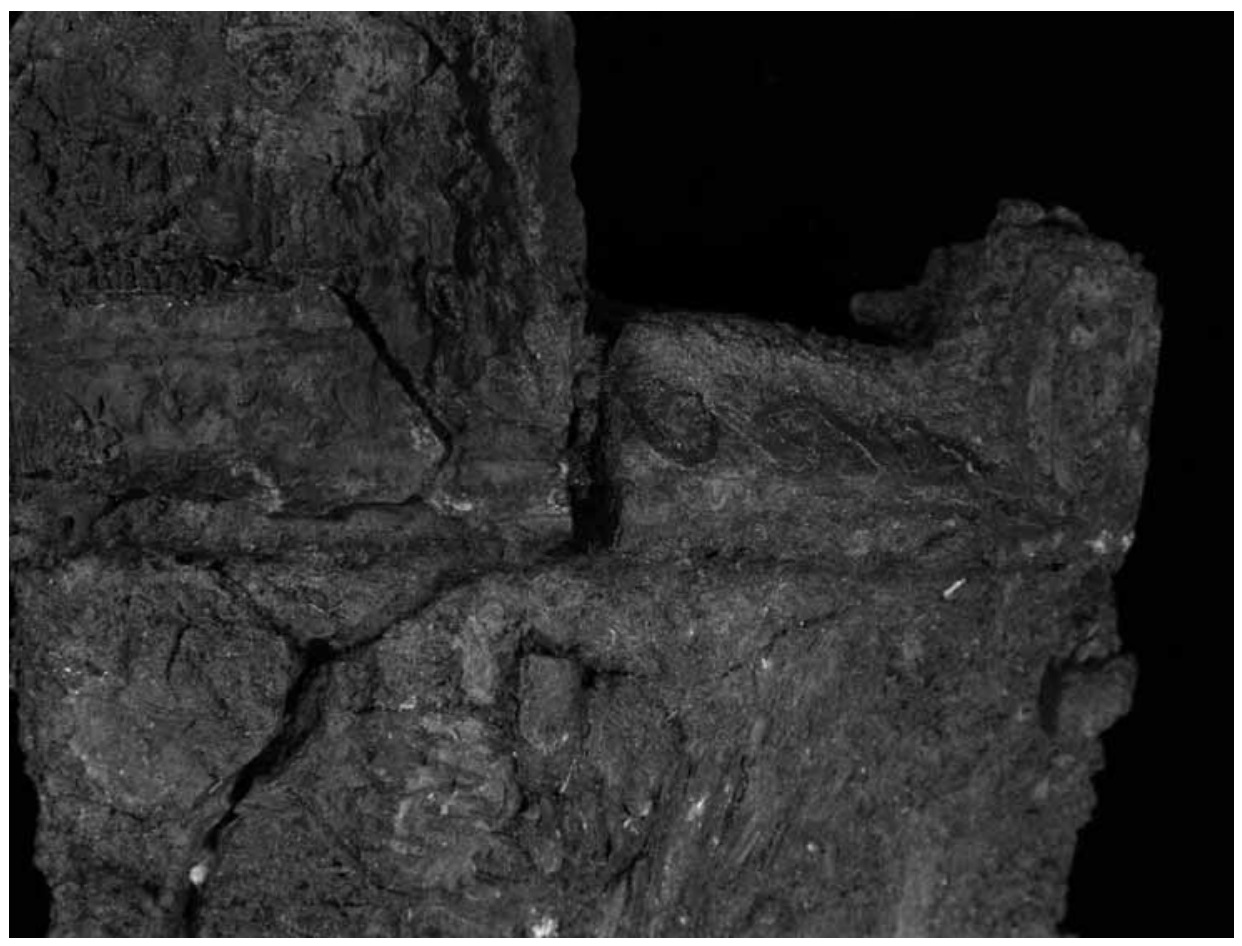

TUMBA 373

\section{Tumba 386}

N. ${ }^{\circ}$ de inventario: 0/49/386/4.

CRONOLOGÍA: 220-190 a. C.

DESCRIPCIÓN: Incompleta en seis fragmentos, uno perteneciente a la empuñadura, otro a la empuñadura en su extremo basal e inicio de la hoja, las demás a la hoja. De ellos, sólo unen entre sí los fragmentos cercanos al extremo distal que son los que se miden. La hoja presenta un aspecto bastante estilizado.

EMPUÑADURA: Aparece muy corrompida por lo que no se puede saber de qué tipo era.

HOJA: Acanaladuras: A pesar del grado de corrosión que presenta la hoja, se aprecia como se ensanchan para luego converger en el extremo inferior

DECORACION: La radiografía indica que aparece decoración también en la parte inferior de la hoja, cuando acaban las acanaladuras y comienza el extremo distal de la hoja. Lleva dos hileras de espirales enlazadas oblicuas que al unirse forman una gran palmeta, cuya composición es difícil de identificar plenamente, aunque el motivo es bastante común mediante hojas de hiedra y zarcillos más o menos estilizados y entrelazados, dejando tallos al exterior. Podría idenficarse con un modelo próximo al número 10 de Fernando Quesada (1997(I):121, figura 66).

MEDIDAS: Longitud máxima conservada (los dos fragmentos que unen de la parte inferior): $28,7 \mathrm{~cm}$; ancho máximo de la hoja: $5,2 \mathrm{~cm}$. la parte más ancha se encuentra en la mitad inferior de la hoja; ancho mínimo de la hoja: $4 \mathrm{~cm}$. 


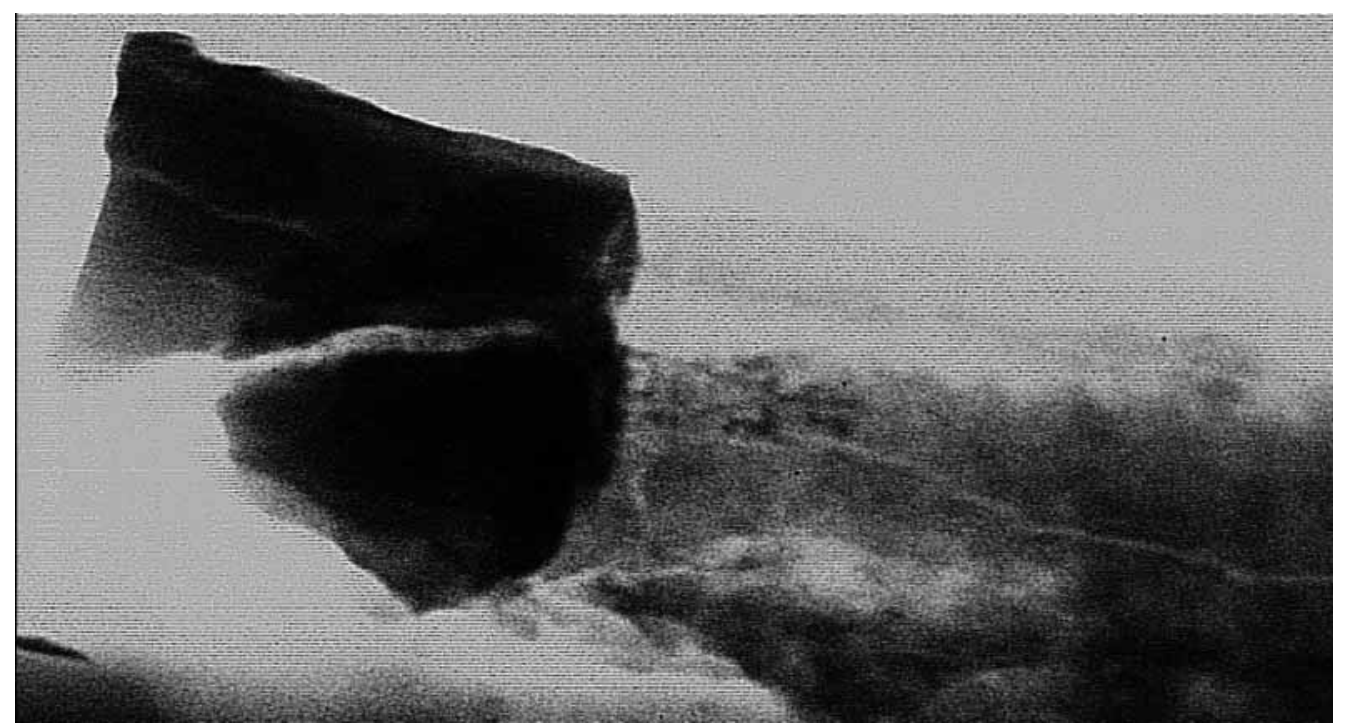

TUMBA 386

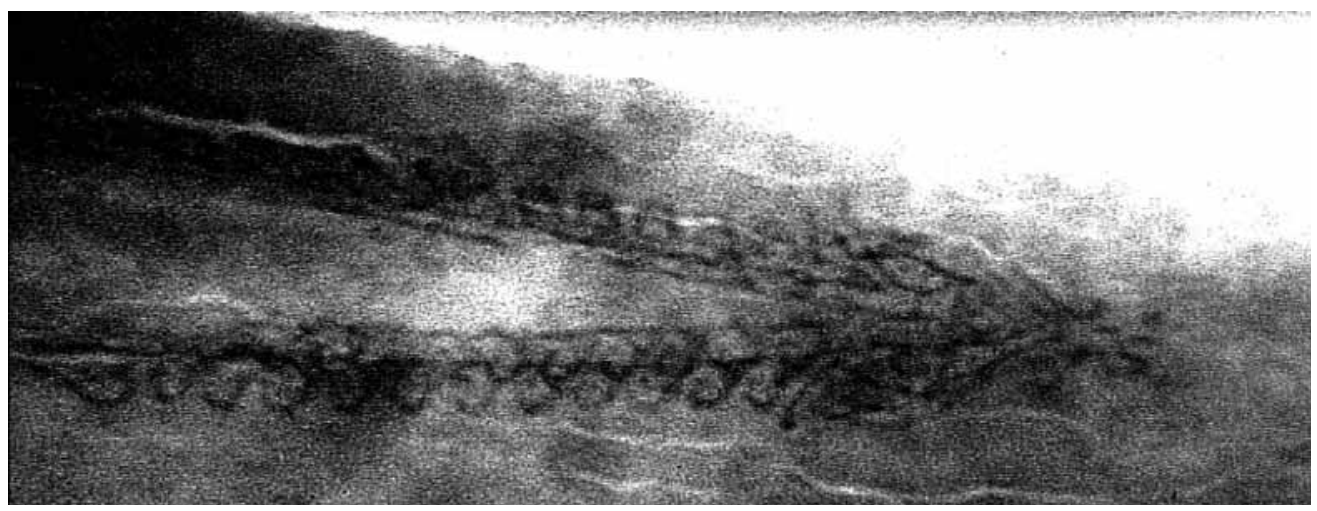

TUMBA 386

\section{Tumba 409}

N. ${ }^{\circ}$ de inventario: 0/49/409/4

CRONOLOGÍA: 375-340 a. C.

DESCRIPCIÓN: Incompleta en tres fragmentos que pertenecen a la hoja. Los trozos no unen entre sí por lo que desconocemos la longitud de la misma.

EMPUÑADURA: En la actualidad perdida.

DECORACION: Apreciamos restos de las incisiones a buril hechas para introducir el damasquinado de plata. La banda que recorría la base de la empuñadura estaba decorada con un zig-zag contínuo y, por encima y debajo, una línea de dientes de lobo o triángulos (Quesada Sanz, 1989(I): 273).

HOJA: Fue doblada intencionalmente presenta un aspecto bastante estilizado y larga. No conserva el extremo distal ni el más cercano a la empuñadura.

Acanaladuras: Con reservas, parecen correr paralelas en toda la mitad superior de la hoja.

DECORACION: La radiografía muestra la decoración en el extremo donde convergen las acanaladuras. Se aprecia una serie de grandes hojas de hiedra de muy buena calidad unidas por esbeltos y largos tallos.

MEDIDAS: Ancho máximo: $5,8 \mathrm{~cm}$. (La anchura máxima conservada en este caso pertenece a la mitad inferior de la hoja); ancho mínimo: $4,2 \mathrm{~cm}$. 


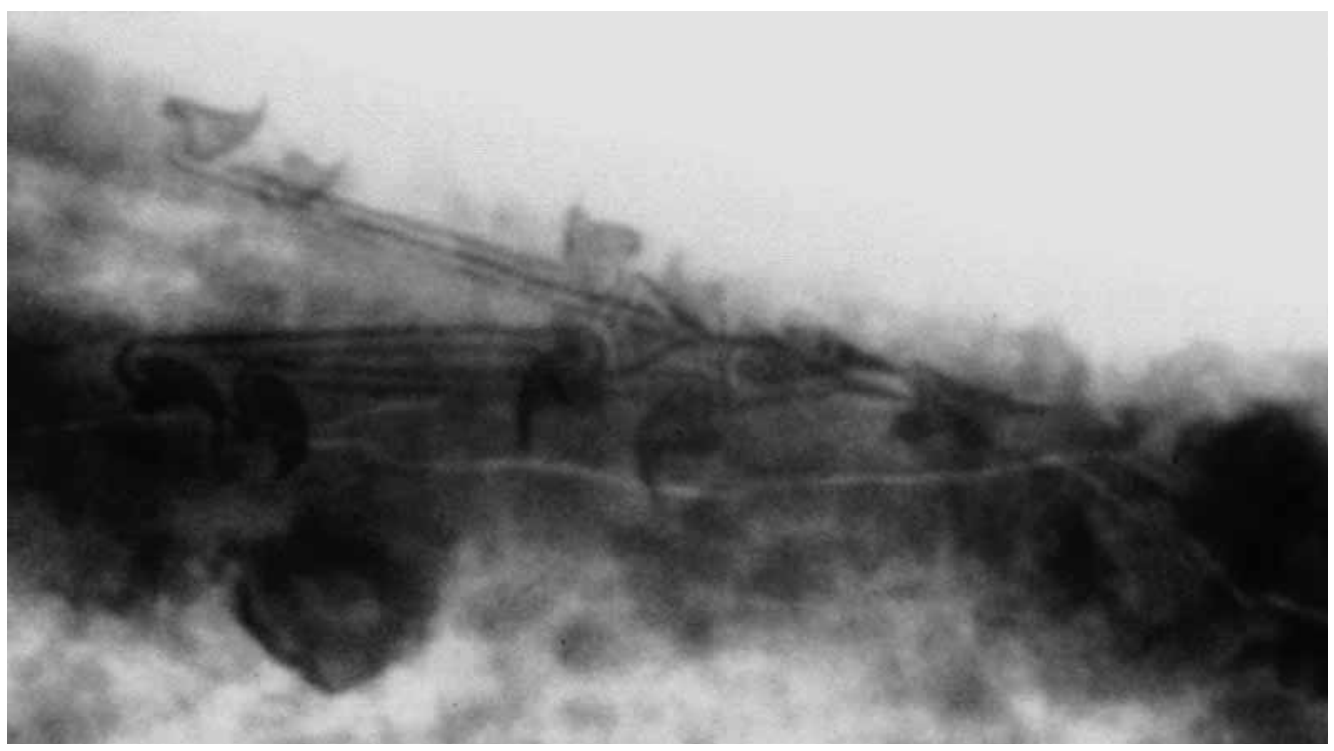

TUMBA 409

\section{Tumba 448}

N. ${ }^{\circ}$ de inventario: 0/49/448/1.

CRONOLOGÍA: Sin datos.

DESCRIPCIÓN: Conserva cinco fragmentos pertenecientes a la hoja y la empuñadura. Tiene un aspecto bastante macizo. La falcata está prácticamente completa excepto el extremo distal y un trozo intermedio donde la hoja se estrecha.

EMPUÑADURA: En forma de cabeza de caballo. Aparece un fragmento de la barra maciza de unión a la guarda, lleva dos remaches.

DECORACION: Damasquinados de plata en la empuñadura. Apenas quedan visibles restos de plata de lo que debió ser decoración de la base de la misma. Sobre ellos aparece una capa de concreciones importante que impide ver los motivos hasta que no se haga una restauración de la pieza.

HOJA: Acanaladuras: Con reservas, divergen al unirse a la empuñadura.

DECORACION: En el extremo donde convergen las acanaladuras. Muestra dos hileras de espirales enlazadas que parten o se rematan en una bella palmeta con desarrolladas volutas terminales y una concepción general del dibujo muy estilizado.

MEDIDAS: Longitud máxima conservada ( de la hoja: 51, $4 \mathrm{~cm}$; anchura máxima de la hoja: 6, $6 \mathrm{~cm}$; anchura mínima: 4, $5 \mathrm{~cm}$.

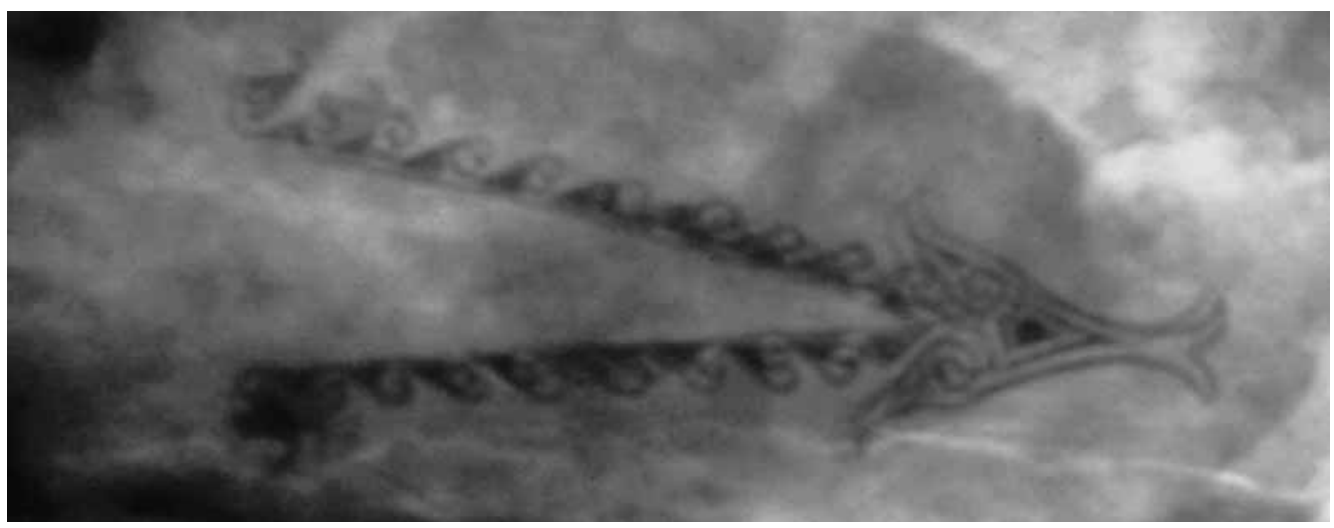

TUMBA 448 


\section{Tumba 453}

N. ${ }^{\circ}$ de inventario: 0/49/453/7.

CRONOLOGÍA: 325-225 a. C.

DESCRIPCIÓN: Está fragmentada en dos partes que unen entre sí.

EMPUÑADURA: Conserva la guarda basal en muy mal estado y el arranque de la empuñadura propiamente dicha. También se aprecian dos remaches.

HOJA: Unicamente se ha preservado el extremo proximal y la mitad superior.

Acanaladuras: Corren paralelas a la hoja y convergen conforme avanzan hacia la mitad inferior de la pieza.

DECORACION: Presenta dos franjas o hileras oblicuas a base de espirales, no se ha documentado la unión de ambas, probablemente es una palmeta al estilo de las aparecidas en las tumbas 160, 198, 386 y 448 de este estudio. Las líneas se inician con un pequeño roleo estilizado para obtener una forma oblicua.

MEDIDAS: Longitud máxima de la pieza conservada: $39,7 \mathrm{~cm}$; longitud máxima de la hoja: $34,2 \mathrm{~cm}$; anchura máxima de la hoja: 6,4 cm; anchura mínima: $4,1 \mathrm{~cm}$.

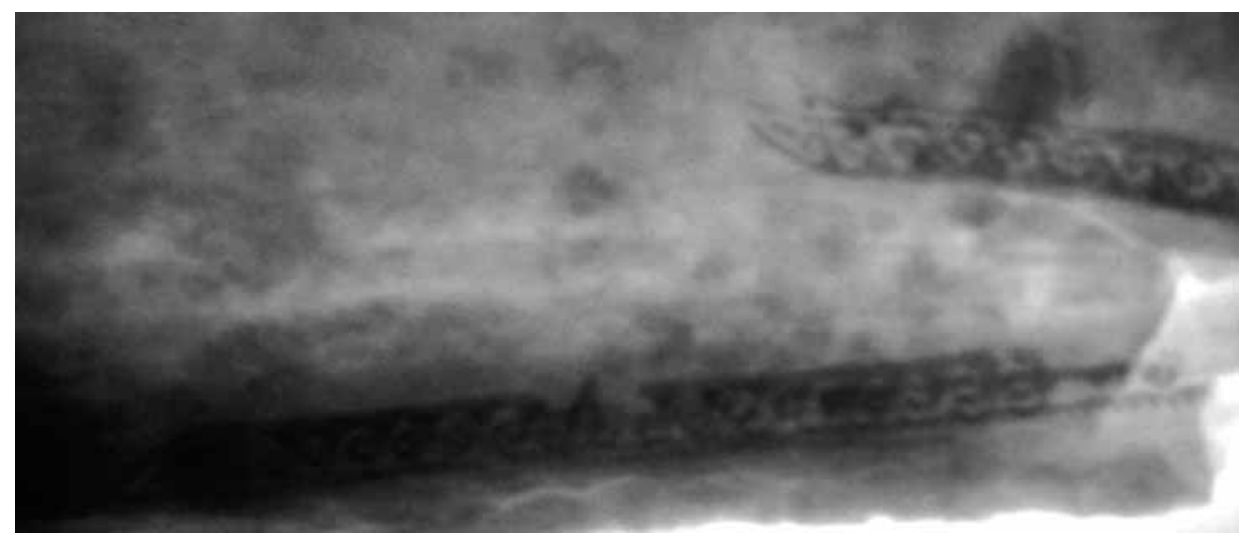

TUMBA 453

\section{Tumba 597}

N. ${ }^{\circ}$ DE INVENTARIO: $1989 / 69 / \mathrm{G}-12 / 249$

CRONOLOGÍA: 400-300 a. C

DESCRIPCIÓN: Completa pero fragmentada. Aspecto más o menos estilizado.

EMPUÑADURA: En forma de cabeza de caballo.

DECORACION: En la empuñadura, guarda basal y hoja. Debió de estar totalmente decorada la guarda lateral, de la que solo se ha preservado el inicio de la misma junto al pomo de la falcata. Los motivos son geométricos que parecen definir cuatro ovas enfrentadas, separadas dos a dos por una línea. La unión con el apéndice también aparece decorado con dos líneas.

La guarda basal se decora de forma completa con motivos geométricos simples a base de líneas quebradas y anchas franjas rellenas con líneas transversales. El dorso tiene este mismo motivo, aunque se inicia con dos líneas quebradas y parece rematarse con otras dos líneas también quebradas y una palmeta de tres pétalos en el centro.

HOJA: Tiene filo en ambos lados a partir de la mitad de la hoja.

Acanaladuras: Divergen al acercarse a la empuñadura.

DECORACION: Lleva los mismos motivos en ambas caras. Junto a la empuñadura un dibujo geométrico sencillo de líneas oblicuas y debajo dos cabezas de cánido con la boca abierta y lengua colgante. Se han trazado opuestas unidas por una orla de espirales dobles enlazadas que otorgan al dibujo en su conjunto una imagen de protomos de perro cogidos por la espalda. Aprovechando la anchura de la falcata en esta parte, sin filo dorsal, se ha trazado en el dorso un conjunto de dos palmetas pegadas por el centro. Un poco más allá en el desarrollo del arma se vislumbran restos de otra palmeta. 
A partir del inicio del filo dorsal del arma se plasma otro nuevo conjunto decorativo formado por un gran friso de 125 milímetros de longitud compuesto por una hilera de dientes de lobo y debajo roleos enlazados. En ambas caras la imagen se culmina con un pez de unos 20 milímetros de longitud. Esta ilustración es única hasta la fecha en las decoraciones de las falcatas ibéricas. Su concepción a base de líneas oblicuas que confluyen en una central nos recuerda mucho a la estructura ósea de los peces con la espina dorsal en el centro y pequeñas espinas a ambos lados de esta. En nuestro caso se culmina el dibujo con la silueta del pez, es decir, se muestra casi como si fuese el resultado de una radiografía.

Este modelo de pez es el que se ha seguido del mismo modo en el célebre lebes aparecido en el departamento 12 del poblado de San Miguel de Liria, conocido como «vaso de la batalla naval», donde completando la escena principal del combate se dibujaron nueve peces (En último lugar y con la bibliografía precedente véase Bonet Rosado, 1995:87, n. ${ }^{\circ}$ 8, figura 27).

MEDIDAS: Longitud máxima: $62,7 \mathrm{~cm}$; longitud máxima de la hoja: 52,9 cm; anchura máxima de la hoja: $6,3 \mathrm{~cm}$; anchura mínima: $3,9 \mathrm{~cm}$.

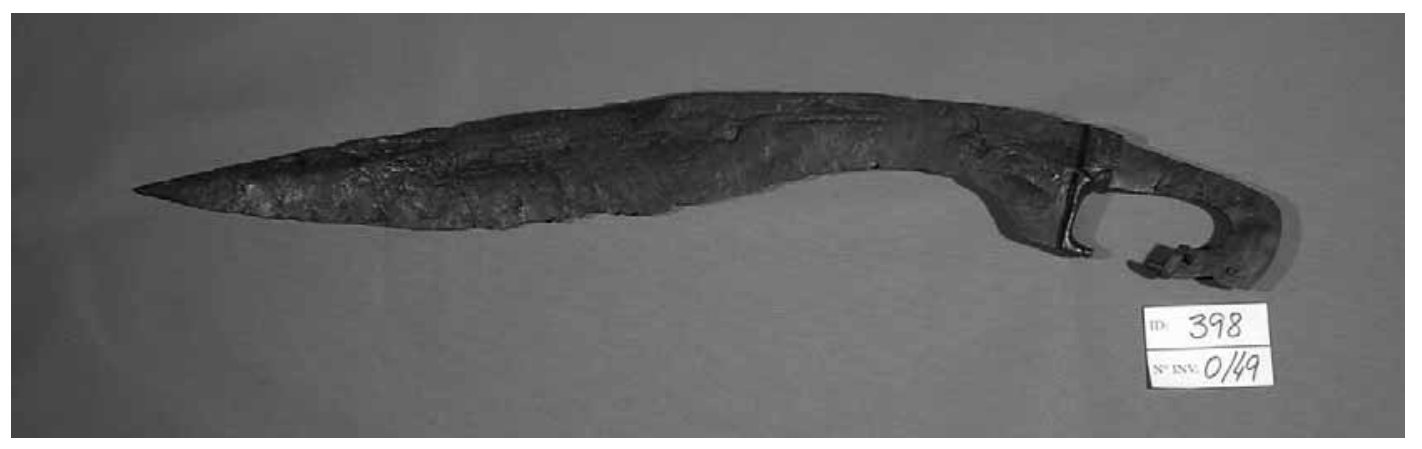

TUMBA 597

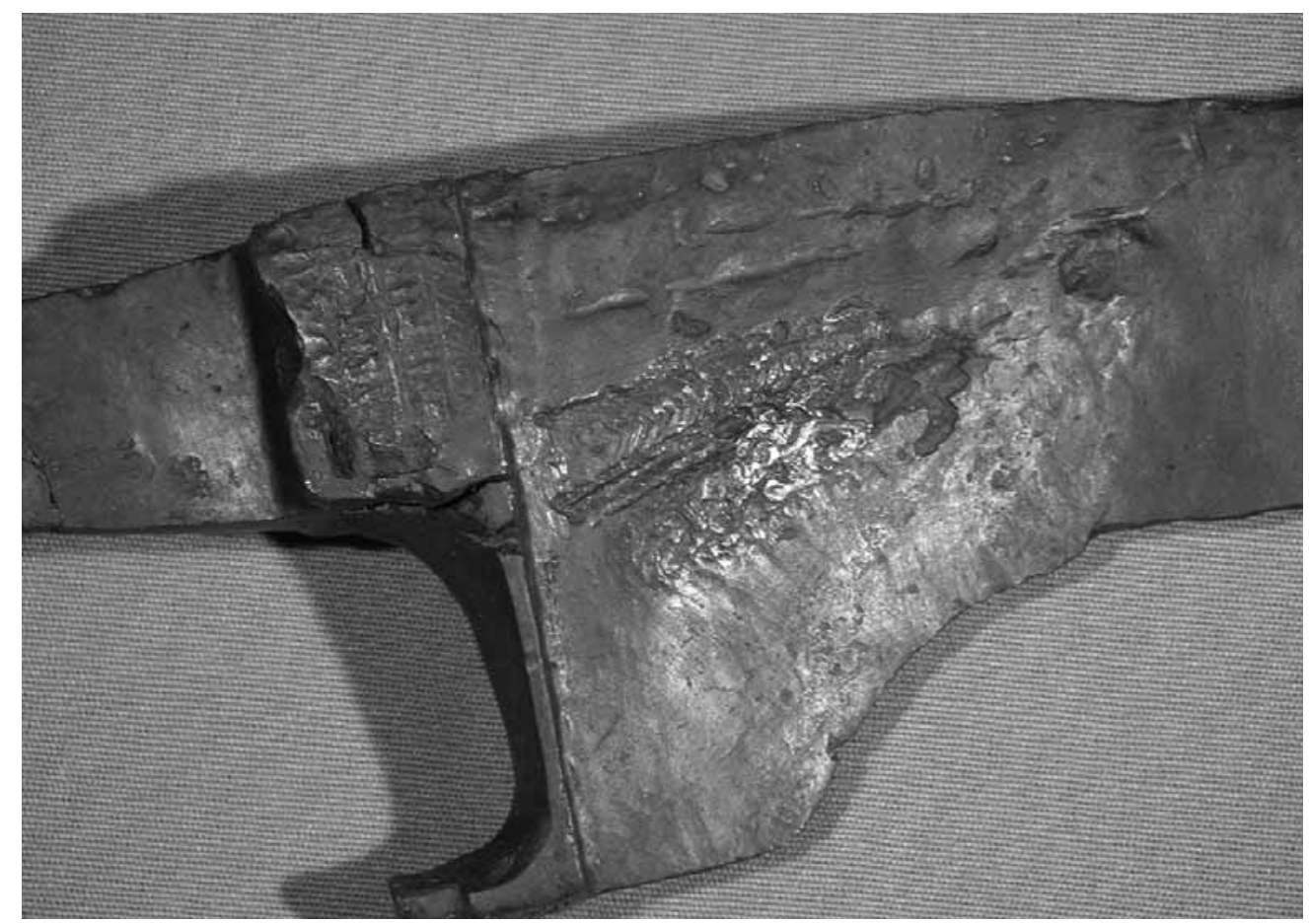

TUMBA 597 


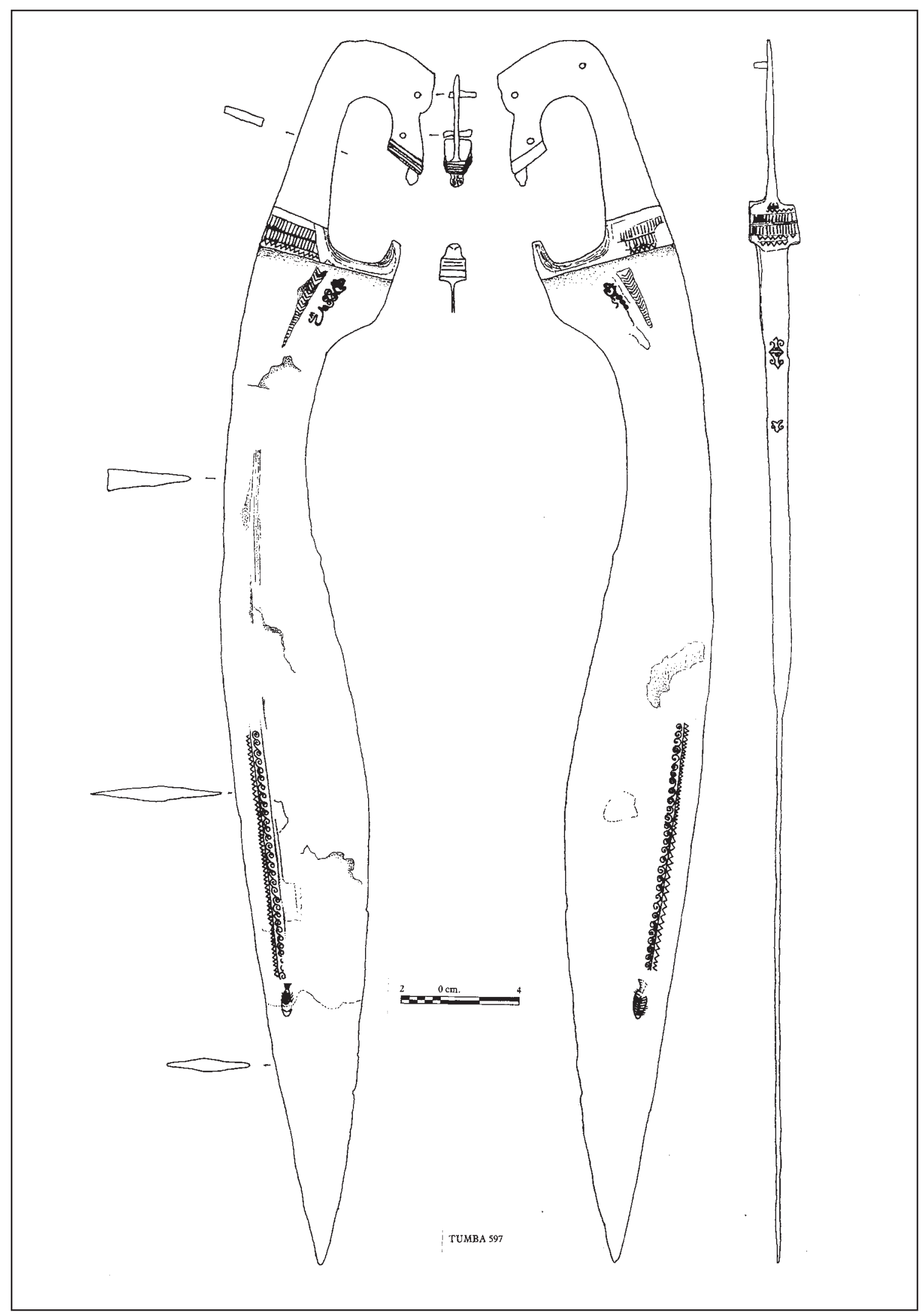

TUMBA 597 


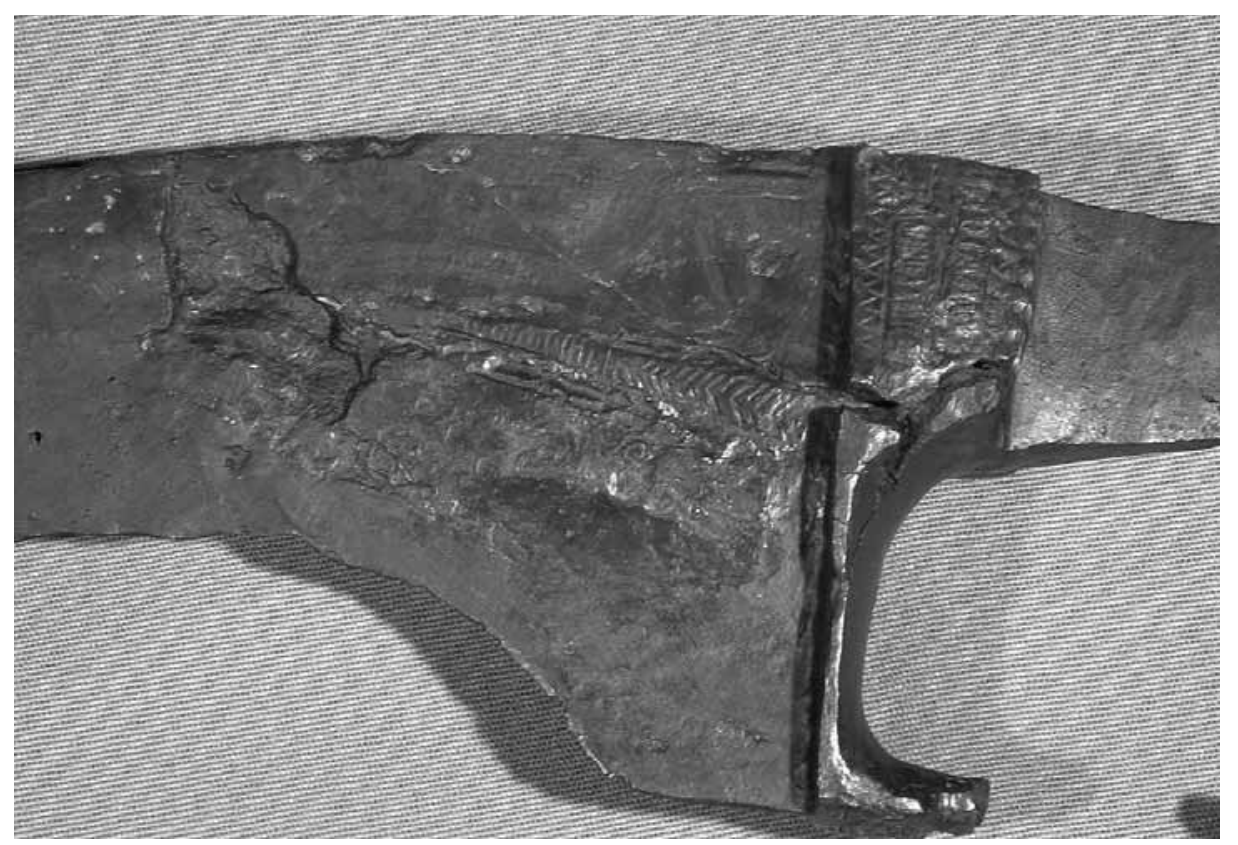

TUMBA 597

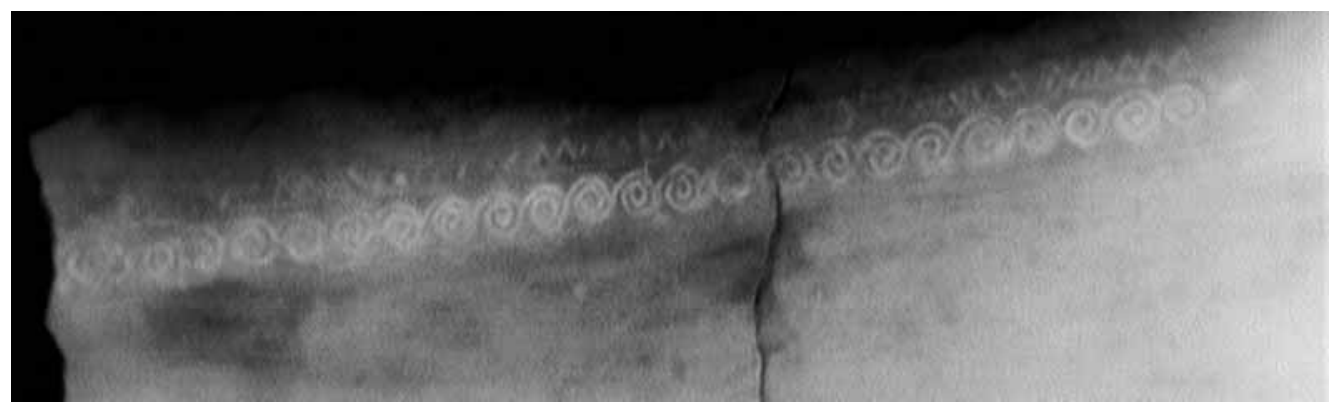

TUMBA 597

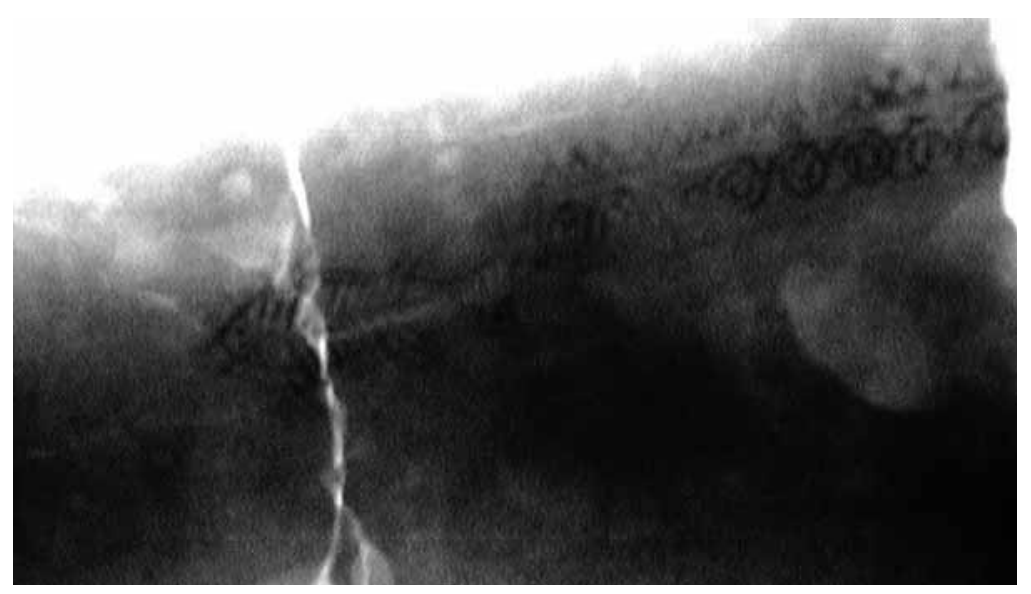

TUMBA 597. Detalle del pez situado junto a la punta de la falcada 


\section{Tumba 608}

N. ${ }^{\circ}$ de inventario: $1993 / 42 / \mathrm{I}-27 / 1024$

CRONOLOGÍA: 400-300 a. C

DESCRIPCIÓN: Completa. Tiene un aspecto macizo.

EMPUÑADURA: Forma de cabeza de caballo. Tiene cinco remaches. Se ha conservado la guarda lateral.

DECORACION: En la guarda basal. Presenta en la parte más ancha, dentro de la cartela, un rectángulo irregular adaptado a la superficie disponible de un motivo a base de ovas enfrentadas. En los lados largos se dibujan en un caso parejas de tres ovas y en los cortos una a cada lado, mientras que en el reverso solo se ejecutaron dos juegos de ovas, aunque de mayor tamaño, en los lados largos.

HOJA: Acanaladuras: Divergen al acercarse a la empuñadura.

MEDIDAS: Longitud máxima: $57,2 \mathrm{~cm}$; longitud máxima de la hoja: $46,6 \mathrm{~cm}$; anchura máxima de la hoja: $5,9 \mathrm{~cm}$; anchura mínima: $3,1 \mathrm{~cm}$.

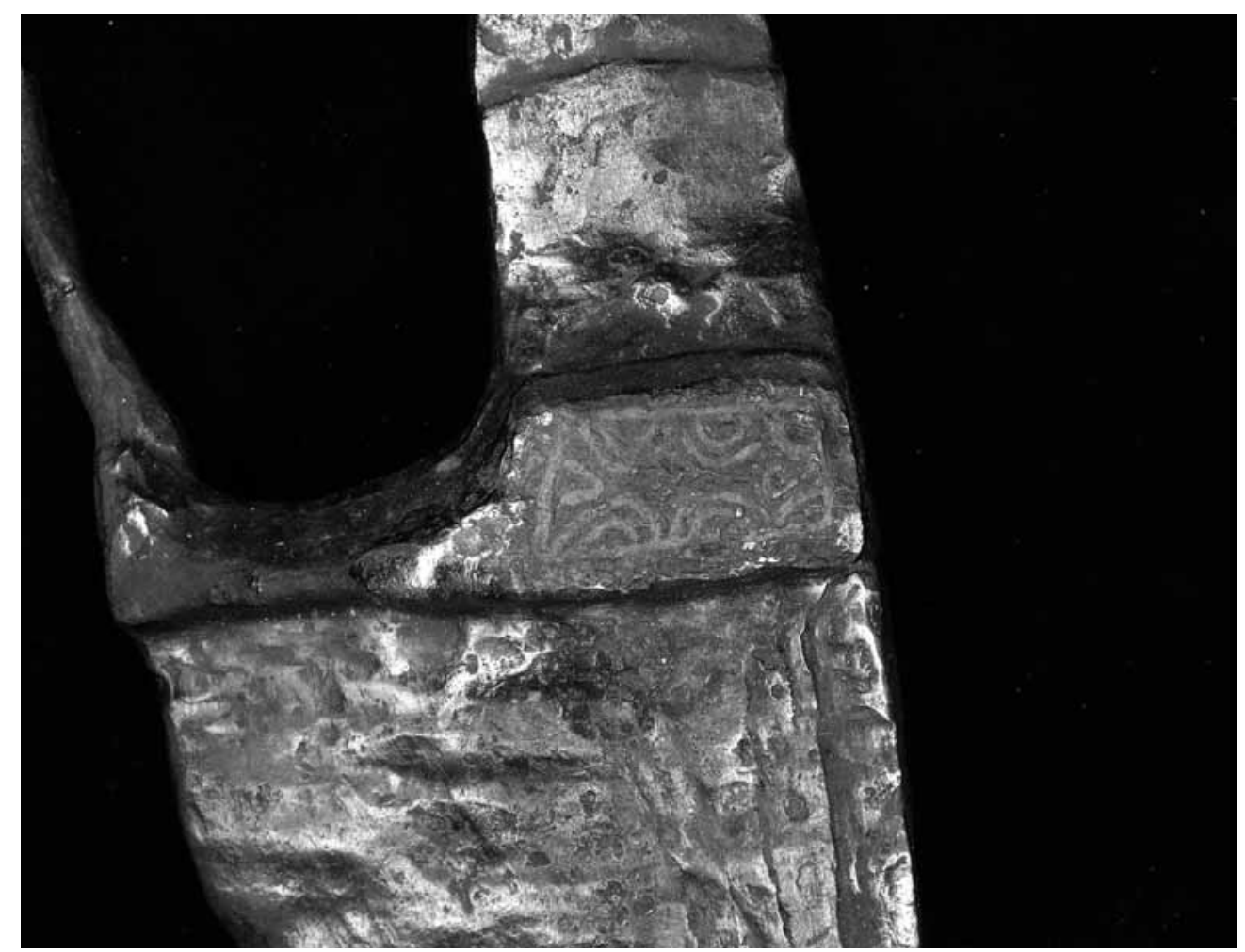

TUMBA 608 


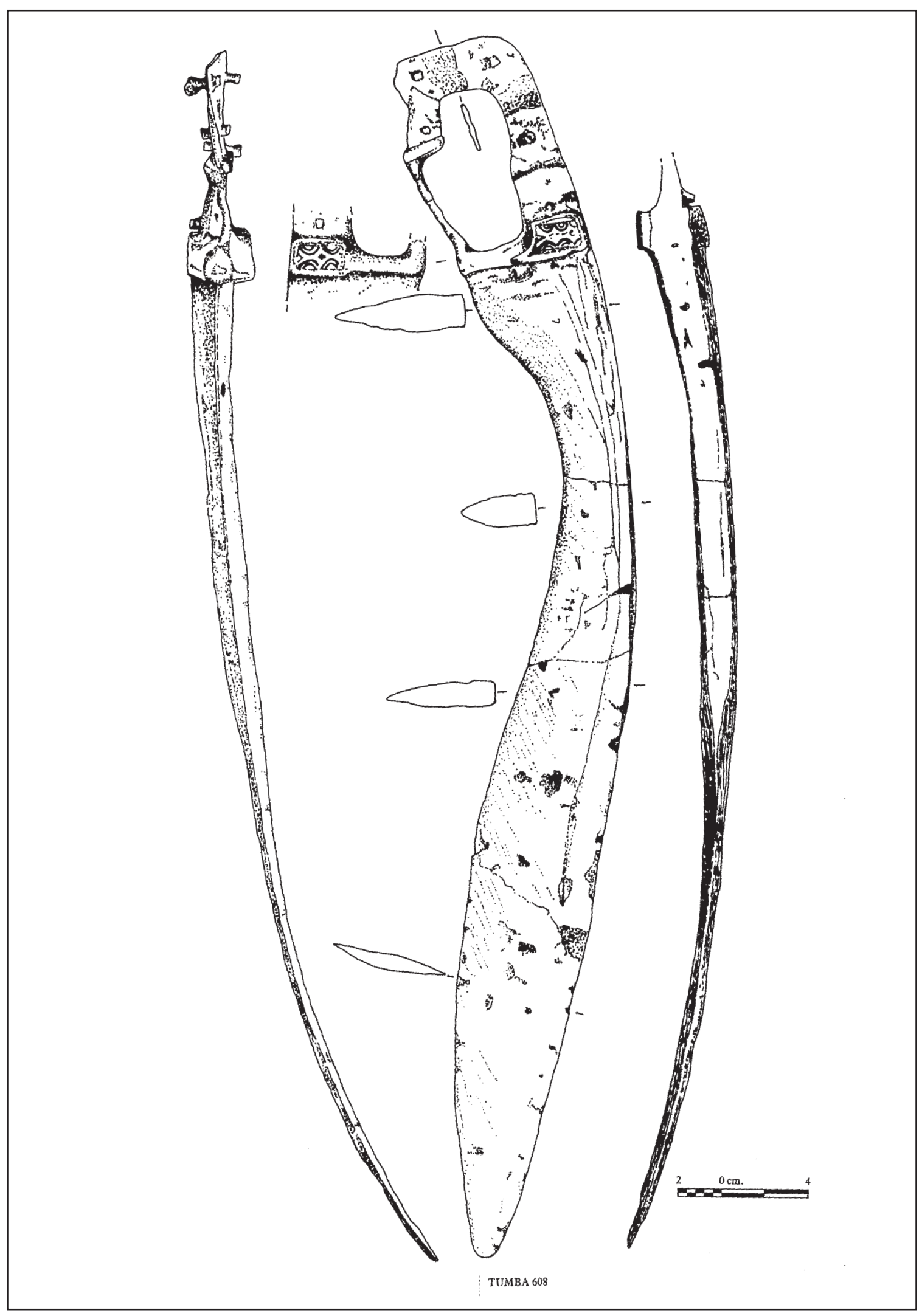

TUMBA 608

Gladius, XXVI (2006), pp. 61-92. ISSN: 0435-029X 


\section{CONSIDERACIONES FINALES}

La realización de las radiografías a los ejemplares estudiados ha podido determinar en los casos en los que el estado de la pieza así lo permitía, algunos aspectos muy interesantes y no evidentes a primera vista, como: el tipo de acanaladuras que presenta la hoja, el grado de corrosión, las restauraciones anteriormente efectuadas y la existencia o no de decoración. Este último punto ha sido trascendental para este trabajo, ya que ha puesto de manifiesto el volumen real de piezas con decoración damasquinada presente en las falcatas ibéricas, cosa que habrá que extender en un futuro próximo al resto de la panoplia, tanto en este como en otros yacimientos ibéricos.

Los motivos estudiados por regla general, se insertan en la tabla elaborada por el profesor Fernando Quesada, aunque logicamente han aparecido nuevas variantes y lo que es más importante, escenas inéditas hasta la fecha, de la relevancia del pez (T.597) o la lucha entre el jabalí y el perro (T.198). Hemos preferido no alterar/completar el cuadro propuesto por F. Quesada (1997(I):121, figura 66), porque pensamos que será mejor esperar un cierto tiempo hasta disponer de nuevas series de piezas procedentes de estudios similares al que nos ocupa, para abordar conjuntamente con el Dr. Quesada la revisión de la tabla inicial.

El trabajo ha puesto de manifiesto de manera indudable que los ajuares con falcatas decoradas del siglo IV son más prominentes (13.3 unidades), en general, que durante las centurias III y II. Del mismo modo las decoraciones zoomorfas novedosas también se asignan a esta cronología, escenas de jabali/cánido (T.198) y el pez (T.597) probablemente pertenecientes a elementos de la aristocracia dirigente de Santa Catalina del Monte.

\section{REFERENCIAS BIBLIOGRÁFICAS}

Aranegui Gascó, C. y E. Pla Ballester, 1981: «La cerámica ibérica». La baja época de la Cultura Ibérica, Madrid 1979, pp. 73-144.

Bonet Rosado, H., 1995: El Tossal de Sant Miquel de Lliria. La antigua Edeta y su territorio. Valencia.

Bosch Gimpera, P., 1924: «Bronzes iberics de La Luz (Murcia) al Museu de Barcelona». Gaseta de les Arts I, 10, pp. 4-5.

Bosch Gimpera, P., 1931: «Troballes del possible santuari iberic de Sant Antoni el Pobre (El Palmar, Murcia), ingresades al Museu de Barcelona». Anuari del Institut d'Estudis Catalans, VII, 19211926, pp. 162-171.

Broncano Rodríguez, S., 1978: La cerámica pintada de la necrópolis del Cabecico del Tesoro, Verdolay, Murcia. Memoria de licenciatura inédita. Universidad Autónoma de Madrid.

Conde Berdos, M. J., 1990: «Los kalathoi sombrero de copa de la necrópolis del Cabecico del Tesoro, Verdolay (Murcia)». Verdolay, 2, pp. 149-160.

Cuadrado Díaz, E., 1977-1978: «Ungüentarios cerámicos en el mundo ibérico. Aportación cronológica». AEspA 50- 51. Madrid, pp. 389- 404.

CuAdRAdo DíAZ, E., 1987: La necrópolis ibérica de «El Cigarralejo» (Mula, Murcia). BPH XXIII. Madrid.

Cuadrado Díaz, E., 1989: La panoplia ibérica de «El Cigarralejo»(Mula. Murcia). Murcia.

FernándeZ de AVilés y ÁlvareZ Ossorio, A., 1940: «Museo Arqueológico de Murcia». Memorias de los Museos Arqueológicos Provinciales I. Madrid, pp. 70-77.

FernÁndez de AvilÉs y Âlvarez Ossorio, A., 1941: «Museo Arqueológico de Murcia». Memorias de los Museos Arqueológicos Provinciales II. Madrid, pp. 97-118.

GarCía CANO, J. M., 1982: Cerámicas griegas de la región de Murcia. Murcia.

García CANo, J. M., 1993: «La necrópolis ibérica del Cabecico del Tesoro (Verdolay, Murcia). Campaña, 1989». Memorias de Arqueología 4 (1989). Murcia, pp. 83-91.

GARCíA CANO, J. M., 1996: «Informe de la segunda campaña de excavaciones en la necrópolis ibérica 
del Cabecico del Tesoro (Verdolay, Murcia). Memorias de Arqueología 5 (1990). Murcia, pp. 105113.

García CANo, J. M., 1997a: Las necrópolis ibéricas de Coimbra del Barranco Ancho (Jumilla, Murcia). I.- Las excavaciones y estudio analítico de los materiales. Murcia.

GaRcía CANO, J. M., 1997b: « Tercera campaña de excavaciones en la necrópolis ibérica del Cabecico del Tesoro (Verdolay, Murcia). Memorias de Arqueología 6 (1991). Murcia, pp. 109-114.

GARCÍA CANO, J. M., 1998: «Cuarta campaña de excavaciones en la necrópolis ibérica del Cabecico del Tesoro (Verdolay, Murcia). Memorias de Arqueología 7 (1992). Murcia, pp. 143-165.

García Cano, J. M., 2006 (e.p.): La necrópolis ibérica del Cabecico del Tesoro (Verdolay, Murcia). Memoria de las excavaciones 1989-1993. Murcia. Entragado a la Dirección General de Cultura de la Comunidad Autónoma de la Región de Murcia para su publicación.

García Cano, J. M. y V. Page del Pozo, 2001: «El armamento de la necrópolis del Castillejo de los Baños. Una aproximación a la panoplia ibérica de fortuna (Murcia)». Gladius XXI. Madrid, pp. 57136.

García CANo, J. M. y V. Page del Pozo, 2004: Terracotas y vasos plásticos de la necrópolis del Cabecico del Tesoro, Verdolay, Murcia. Monografías del Museo de Arte Ibérico de El Cigarralejo 1. Murcia.

García Cano, C, J. M., García Cano y E. Ruiz Valderas, 1989: «Las cerámicas campanienses de la necrópolis ibérica del Cabecico del Tesoro», Verdolay 1. Murcia, pp. 117-189.

García SAndoval, E., 1962: La cerámica precampaniense y campaniense del Cabecico del Tesoro. Tesis de licenciatura inédita. Universidad de Murcia.

HeRnÁndeZ AlCARAZ, L., 2005: «Una panoplia ibérica con armamento decorado de la necrópolis del Puntal (Salinas, Alicante)». I Jornadas de Arqueología Ibérica organizadas por el Area de Arqueología de la Universidad de Alicante 24-26 de octubre de 2002. Alicante, pp. 385-392.

Iniesta SANMARTín. A., 1983: Las fíbulas de la región de Murcia. Murcia.

Jorge ARAgONESES, M., 1968: «La badila ritual ibérica de La Luz (Murcia) y la topografía arqueológica de aquella zona según los últimos descubrimientos». Anales de Filosofía y Letras de la universidad de Letra, XXVI-2. Murcia, pp. 317-346.

Jorge Aragoneses, M., 1973: «Bronces inéditos del santuario ibérico de La Luz, Murcia». Homenaje a Federico Navarro. Madrid, pp. 197-225.

Lillo CARPIO, P. A., 1991-1992: «Los exvotos de bronce del Santuario de La Luz y su contexto arqueológico (1990- 1992)». Anales de Prehistoria y Arqueología de la universidad de Murcia 7-8. Murcia, pp. 107-142.

Lillo CARPIO, P. A., 1993-1994: «Notas sobre el templo del santuario de La Luz (Murcia)». Anales de Prehistoria y Arqueología de la universidad de Murcia,9-10. Murcia, pp. 155-174.

Lillo CARPIO, P. A., 1995-1996: «El peribolos del templo del santuario de La Luz y el contexto de la cabeza marmórea de la diosa». Anales de Prehistoria y Arqueología de la universidad de Murcia 11- 12. Murcia, pp. 95-128.

Lillo CARPIO, P. A., 1996: «Excavaciones en el santuario de La Luz, campaña de 1990». Memorias de Arqueología 5 (1990). Murcia, pp. 87-103.

Lillo CARPio, P. A., 1997: «Excavaciones en el santuario de La Luz. Campaña de 1991». Memorias de Arqueología 6 (1991). Murcia, pp. 115-135.

Lillo CARPIO, P. A., 1998: «Excavaciones en el santuario de La Luz. Campaña de 1992». Memorias de Arqueología 7 (1992). Murcia, pp. 121-141.

Lillo CARPio, P. A., 1999: «Excavaciones en el santuario de La Luz. Campaña de 1994». Memorias de Arqueología 9 (1994). Murcia, pp. 223-235.

Lillo CARPIO, P. A., 2002a: «Excavaciones en el santuario de La LuZ». Memorias de Arqueología 10 (1995). Murcia, pp. 201-212.

Lillo CarPio, P. A., 2002b: «Excavaciones en el santuario de La Luz (sector templo). Campaña de 1996». Memorias de Arqueología 11 (1996). Murcia, pp. 205-217.

Lozano Santa, J., 1794: Bastitania y Contestania del Reyno de Murcia. Murcia (2 volúmenes).

Mergelina y Luna, C., 1924-1925: «El Santuario Hispánico de la sierra de Murcia. Memoria de las excavaciones en el Eremitorio de La Luz.» Memoria de la Junta Superior de Excavaciones y Antigüedades 7. Madrid.

Morel, J. P., 1981: Cerámica campanienne. Les formes. BEFAR 242. Roma. 
Muñoz Amilibia, A. M., 1963: Pebeteros ibéricos en forma de cabeza femenina. De Coroplastia ibérica 1. Barcelona.

Nieto Gallo, G., 1939-1940: «Noticia de las excavaciones realizadas en la necrópolis del Cabecico del Tesoro (Verdolay, Murcia)». BSAA, VI. Valladolid, pp. 137-160.

Nieto Gallo, G., 1942-1943: «La necrópolis hispánica del Cabecico del Tesoro, Verdolay (Murcia). III Campaña de excavaciones (octubre de 1942)». BSAA, IX. Valladolid, pp. 191-196.

Nieto Gallo, G., 1943-1944: «La necrópolis hispánica del Cabecico del Tesoro, Verdolay (Murcia). IV Campaña de excavaciones»BSAA, X. Valladolid, pp. 165-175.

Nieto Gallo, G., 1947: «La necrópolis hispánica del Cabecico del Tesoro, Verdolay (Murcia)». III CASE. Murcia, pp. 176-183.

Nieto Gallo, G. y Escalera UreñA, 1970: «Estudio y tratamiento de una falcata de Almedinilla». Informes y Trabajos del ICROA 10. Madrid, pp. 5-30.

Page Del Pozo, V., 1984: Imitaciones de influjo griego en la cerámica ibérica de Valencia, Alicante y Murcia. Iberia Graeca. Serie Arqueológica I. CSIC. Madrid.

Page del Pozo, V y J. M. García CANo, 1993: «La escultura en piedra del Cabecico del Tesoro (Verdolay, La Alberca, Murcia). Verdolay, 5. Murcia, pp. 35-60.

Poyato Holgado. M. C., 1975: Los kálathos ibéricos de la necrópolis del Cabecico del Tesoro, Verdolay, Murcia. Tesis de licenciatura inédita. Universidad Autónoma de Madrid.

Poyato Holgado, M. C., 1979: «Sector D: Cerro de Santa Catalina del Monte, Verdolay (Murcia). Ampurias 38- 40. Ampurias 1977. Barcelona, pp. 531-543.

QuesadA SAnZ, F., 1988: «Las acanaladuras en las hojas de las falcatas ibéricas.»CuPAUAM 15. Madrid, pp. 275-299.

QuesadA SANZ, F., 1986-1987: «El armamento de la necrópolis ibérica de «El Cabecico del Tesoro (Murcia)». CUPAUAM. 13-14(II). Madrid, pp. 47-64.

Quesada SAnZ, F., 1989:»Armamento, Guerra y Sociedad en la necrópolis ibérica del Cabecico del Tesoro, (Verdolay, Murcia. España)». Bar International Series, 502. Oxford,. (II volúmenes).

QuesadA SANZ, F., 1990: «Falcatas ibéricas con damasquinados en plata». Verdolay, 2. Murcia, pp. 4560.

Quesada SANZ, F., 1997: El armamento ibérico. Estudio tipológico, geográfico, funcional, social y simbólico de las armas en la cultura ibérica (siglos VI-I a.C.). Monographies Instrumentum 3 (II volúmenes). Montagnac.

Reig SEgui, C., 2000: «El armamento de la necrópolis ibérica de la Serreta de Alcoi (Alicante, España)». Gladius XX. Madrid, pp. 74-117.

Ros SAlA, M. M., 1988: «El poblado de Santa Catalina del Monte: Una aproximación a la urbanística del siglo VI a. C en el ámbito territorial del eje Segura- Guadalentín». CuPAUAM 13-14. Madrid, 1986-1987, pp. 77-88.

Ros Sala, M. M., 1989: Dinámica urbanística y cultura material del Hierro Antiguo en el Valle del Guadalentín. Murcia.

Ruiz Bremón, M., 1991: «La supuesta dama sedente del Cabecico del Tesoro (Verdolay, Murcia)». AEspA 64. Madrid. pp. 83-97.

Ruiz Sanz, M. J., 1998: «Excavaciones de urgencia en el poblado de Santa Catalina del Monte (Verdolay, Murcia)». Memorias de Arqueología 7 (1992). Murcia, pp. 77-116.

Sala Selles, F. y L. Hernández Alcaraz, 1998: «La necrópolis de El Puntal (Salinas, Alicante): Aspectos funerarios ibéricos del siglo IV a.C. en el corredor del Vinalopó». Cuadernos de Prehistoria y Arqueología Castellonenses 19. Castellón, pp. 221-266.

SÁnchez Meseguer, J., y F. Quesada SAnz, 1992: «La necrópolis ibérica del Cabecico del Tesoro (Verdolay, Murcia)». Congreso de Arqueología ibérica. Las necrópolis. Universidad Autónoma de Madrid. Madrid, pp. 349-397.

SAnmartí Grego, E., 1973: «El taller de las pequeñas estampillas en la península Ibérica». Ampurias 35. Barcelona, pp. 135-173.

Recibido: 20/07/2006

Aceptado: 19/10/2006 